\title{
The Celestial Ferryman in Ancient Egyptian Religion "Sailor of the Dead" Dr.Radwan Abdel-Rady Sayed Ahmed*
}

\section{Abstract:}

In the ancient Egyptian religion, the ferryman was generally called (Hr.f-h3.f) and depicted as a sailor or a boatman standing in the stern of a papyrus boat.

The Egyptian ferryman is known from the funerary texts: Pyramid Texts of the Old Kingdom, Coffin Texts from the Middle Kingdom, Book of Dead from the New Kingdom, texts from Greco-Roman temples and other textual resources in about 21 names and titles.

It was necessary for the deceased to summon a ferryman at his crossing, that he would navigate the soul through the winding waters of the Underworld, naturally by means of a magic formula, in which the mystic name of the ferryman was contained.

In all of these sources we find his names, titles, epithets, roles, functions, and relations with other deities of ancient Egypt.

As he was a god in the Netherworld and the ferryman of the dead, he may be the origin of the Greek ferryman CHARON of HADES.

The idea of the ferryman of Netherworld is not found in ancient Egypt and Greece only, but also found in other ancient cultures as in Yorubas of south Nigeria, Mesopotamia, Ancient Europe, Rome, and Norse (Bronze-Age of Denmark).

The paper will try to give a detailed idea about this important and sacred personality in the Underworld and in ancient Egyptian

\footnotetext{
* Lecturer of Egyptology, Egyptology Department, Faculty of Archaeology - Aswan University, Aswan, Egypt. radluxegy@yahoo.com

My thanks, gratitude and affection to Professor Penelope Wilson (England) and Dr. Ayman Wahby Taher (Egypt) for their help and useful notes as they gave a final revision for the manuscript and correction the English writing.
} 
religious beliefs through the textual sources from different periods and comparable ideas from other cultures.

\section{Key Words}

Celestial Ferryman, Assistant of Boatman (Aken), Dead, Ferryboat, Netherworld, Iaru-fields ,Names \& Titles, Rule, Pyramid Texts, Coffin Texts

\section{Introduction}

In the ancient Egyptian religion, the ferryman was the patron and custodian of the boat that carried the souls of the dead into the Underworld.

Apparently the ferryman assistant $~ k n$ remained in a deep sleep when he was not needed, and had to be woken by the dead who summoned him when he required his services.

He was generally called ( $H r . f-h 3 . f)$ and depicted as a sailor or a boatman standing in the stern of a papyrus boat.

He was not of the focus of worship, and had no particular cult centre or a temple in ancient Egypt.

$\mathrm{He}$ is referred to a number of times and is mentioned frequently in the Pyramid Texts from Old Kingdom, the Coffin Texts from Middle Kingdom, the Book of the Dead from New Kingdom, texts from Greco-roman period and other textual sources.

In all of these sources we find his names, titles, epithets, roles, functions, and relations with other deities of ancient Egypt.

As he was a god in the Netherworld and the ferryman of the dead, he may be the origin of the Greek ferryman CHARON of HADES.

In the following, we will try to form a detailed idea about this important and sacred personality in the Underworld and in ancient Egyptian religious beliefs through the textual sources from different periods.

\section{I-Who is the ferryman of the Netherworld ?}

The celestial ferryman of ancient Egypt is a deity of different names. First attested in the Pyramid Texts of Old Kingdom, as the boatman of dead he was supposed to ferry the deceased king 
across the shifting waterway to the abode of $\mathrm{Re}$, or to the Afterlife sht-htpw "field of offerings" (see name number: 17). The divine ferryman is known as $H r . f-h 3 . f$ "He whose face is behind him" (see names numbers: 3-6) or by any of a dozen other names many of which have similar meaning such as M33- $h 3 . f$ "Whose sight is behind him" (see names numbers: 1-2), and which seem to be linked to his role.

This sacred person as a god is sometimes depicted in the vignettes of the New Kingdom funerary texts seated in his barque and being hailed by the deceased.

In the Papyrus of Anhai he is shown, according to many of his descriptive names, with his head facing backwards (fig. 1 a,b).

$\mathrm{He}$ is less frequently attested in later periods ${ }^{1}$.

$\ulcorner\mathrm{kn}$-The ferryman assistant in the Underworld (see names numbers: 7,8 ).

The two ferrymen M33- $h 3 . f$ and $\mathrm{C} k n$ may also have been understood as the guards of Osiris. In PT. 1201a, the ferryman $M 33-h 3$. $f$ is said to be a gate keeper of Osiris. The name ${ }^{~} k n$ has been compared with the $\mathrm{knn.w}-\mathrm{hr}$, who guards the place of Embalming according to CT spell 49 (CT. I, $218 \mathrm{~b})^{2}$.

\section{II-Writings of the ferryman's names}

The names will be discussed here in chronological order:

\section{1-M33-h3.f "Who sees behind him".}

This name is first attested in the Pyramid Texts of O.K. as a name of the ferryman in the heaven ${ }^{3}$.

It occurs also in the Coffin Texts of M.K

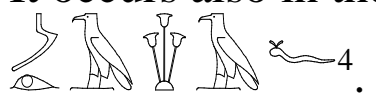

\footnotetext{
${ }^{1}$ Wilkinson, R.H., Complete Gods and Goddesses, p. 104; PT. 999; Lurker, M., Götter und Symbole ss. 180-181.

${ }^{2}$ PT. 1201 a; CT. I, 218 b.

${ }^{3} \mathrm{~Wb}$ II, 10 (5); PT. 597.

${ }^{4}$ CT IV, 367e.
} 
M33- $n-h 3 . f$ "Who sees from his behind", or "Who looks to his behind?".

$M n-h 3 . f^{6}$ which probably means "Whose back is firm ?".

And continued in the funerary N.K. Book of Dead:

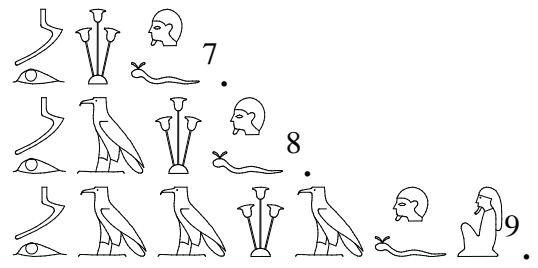

And in the Greco-Roman period:

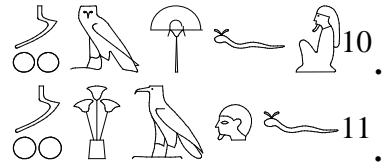

"Who-looks-behind-him" is the traditional translation for the Egyptian expression M33- $h 3 . f$, one of three names. According to them, the ferryman was known in the Egyptian Pyramid Texts. The two other names are:

Hr.f-h3.f "Whose face is behind him" and Hr.f-m-hnt.f-hr.f-m$m h$. $f$ "Whose face is in his front, Whose face is in the back of his head".

The verb $M 33$ as a part of the name $M 33-h 3 . f$, the verb does not mean "look upon" or "look at", but the verb means basically "see".

${ }^{5} \mathrm{CT} \mathrm{V}, 73 \mathrm{n} \& 74 \mathrm{i}$; ${ }^{\mathrm{mm}}$ is a repeated writing form for verb M33 in Pyramid Texts, 299; 439; 448: Faulkner, R.O., Middle Egyptian, p. 100.

${ }^{6} \mathrm{CT}$ VI, 20r; $m 33-h 3 . k$ : 29b; LGG III, 201-202. It is a rare, strange and unique writing form for verb $M 33$ in Coffin Texts (may be a corrupt writing?); Rami van, D.-M., Dictionary of Coffin Texts, pp. 152-153.

${ }^{7} \mathrm{~Wb}$ II, 10 (5).

${ }^{8}$ LGG III, 201

${ }^{9}$ Lapp, G., The Papyrus of Nu ( BM E 10477 ), p. 93, sheet 20, line 9; Lapp, G., "The Papyrus of Nu", PP. 263-264; Louise, G., Die "Textschmiede" , ss. 83-99.

${ }^{10}$ Maspero, G., Sarcophages (CG 29305), p. 11.

${ }^{11}$ Faulkner, R.O., Papyrus British Museum 10569, pp. 33, 26. 
The name also does not describe a self-desire in the case of turning face at looking, but just a physical description for seeing ${ }^{12}$.

\section{2-M33-m-hr.f "Who looks with his face".}

This name is first occurred in the Pyramid Texts of O.K. as a name of the celestial ferryman in the astronomical concepts of the Netherworld:

And in the Greco-Roman period:

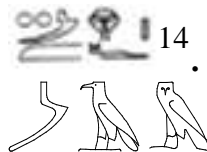

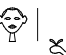

M3-m-hr.f, an epithet of some deity, but its meaning is not obvious; a possible interpretation is (He who sees with his face) ${ }^{15}$.

\section{3-Hr.f-h..$f$ "Whose face (sight) is behind him".}

A name for the celestial ferryman known since the Pyramid Texts:

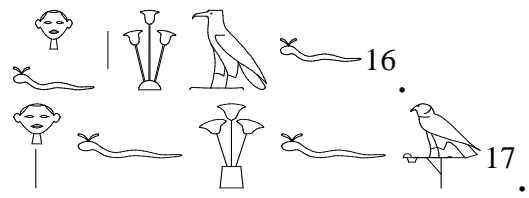

It is an adverbial nominal sentence forming as a name of the celestial ferryman ${ }^{18}$.

And in the Coffin Texts:

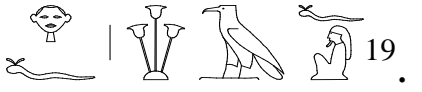

\footnotetext{
${ }^{12}$ Depuydt, L., "Hintersichschauers", pp.33-35. It maybe refers to the way the ferryman stands in a boat with his head turned to see the way he is going, according to a view of point to Professor Penelope Wilson as she made a final revision for the manuscript.

${ }^{13}$ PT. 1059e; Krauss, R., Astronomische Pyramidentexten, s. 67; LGG III, 202.

${ }^{14}$ Speleers, I., Recueil des Inscriptions Égyptiennes, p. 361, 51; LGG III, 202.

${ }^{15}$ Faulkner, R. O., "Gissen Papyrus ", p. 67, fragment1, line1 and commentary p. 71; LGG III, 202.

${ }^{16}$ Wb III, 127 (11-12); PT. 1091 a.

${ }^{17}$ PT. 1091 a.

${ }^{18}$ Edel, E., Alt Ägyptische Grammatik, s. 595 (28).

${ }^{19}$ CT II, 138f; III, 174i; VI, 3c, 23e.
} 


\section{'Iw- $h r . f-h 3$ "Whose face is behind" 20 .}

The construction of the adverbial sentence in $H r . f-h 3 . f$ "Whose face is behind him" does not express the action one expects from the ferryman according to the analysis mentioned above, but expresses just a state of circumstance.

The expression $H r . f-h$. $f$ does not mean that the ferryman turns his head forward and backward, but his face is turning backward like noses and faces of the demons ${ }^{21}$.

\section{4-Hr.f-m-h3.f "Whose face is in his back or behind him".

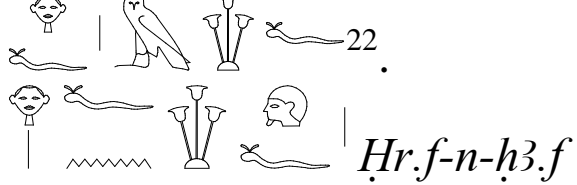

These writings of the ferryman's name are dated to Dynasties: $21-24^{23}$.

\section{5-Nb-hr.f-h3.f "Lord (God), whose face is behind him"24.}

This name occurred in N.K., Saite and Greco-Roman periods. 6-Hr.f-m-hnt.f "Whose face is in his front".

\section{back",25.}

; Also Hr.f-m-mh3.f "whose face is in his

This name is first attested in the Pyramid Texts (O.K.)

Hr.f-m-hnt.f-hr.f-m-mh3.f "His sight is in his face, his sight is in his nick".

\footnotetext{
${ }^{20}$ LGG V, 303.

${ }^{21}$ Depuydt, GM. 126, p. 35 . It is the way the ferryman rows the boat with his neck turned to face the way he is going, according to a view of point to Professor Penelope Wilson as she made a final revision for the manuscript.

${ }^{22} \mathrm{~Wb}$ III, 127 (13). In this name the word $h 3$ is presented here with the nominal prefix

23 Blackman, A. M., “pap. Skrine, no. 2“, pp. 28-29.

${ }^{24}$ Buhl, M.-L., Anthropoid Sarcophagi, p. 57 \& abb. 22; Koefed-Petersen, O., Catalogue des Sarcophages, p. 36.

${ }^{25}$ Wb III, 127 (13); PT. 493b; LGG V, 304; Depuydt, GM. 126, p. 36.
} 


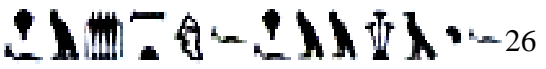

Concerning this name, Sethe thought that the man at steering the boat is nearly looking at his front and nearly looking at his back. The word nearly is in his translation for the name:

"O you, your face nearly is in your front, your face nearly is behind your head".

On contrast of Sethe's suggestion by comparing this meaning with the PT.1221 in a description of a demon or a genii whose locks are in different parts of his head (in front, on temples, and in behind) at the same time.

That means Hr.f-m-hnt.f-hr.f-m-mh3.f has a face in the front and a second face in the back. In addition the PT text 493 is the unique proof that the determinative $\curvearrowright$ in the word $(m) h 3$ gives the meaning "the back part of the head".

It is acceptable that the three names describe the same member of the Egyptian pantheon. This depends on the fact that the two names of both ferrymen have appeared in the same context of the inscriptions, they are:

M33- $h 3 . f$ and $H r . f-h 3 . f$. They were mentioned in two texts: PT. $383 \mathrm{a}$ and $1227 \mathrm{a}$.

$H r . f-m-h n t . f-h r . f-m-m h 3 . f$ is similar to $H r . f-m-m h 3 . f$ the owner of the name $H r . f-h 3 . f$.

In addition, one of the forty-two judges in the Book of the Dead bears the name $H r . f-h 3 . f$, the relationship with the ferryman was not clear in the time of Old Kingdom ${ }^{27}$.

\footnotetext{
${ }^{26}$ PT. 493b; Lacau, M., Parties du Corps, p. 35.

Urk. IV, 697, 13) the writer succeeded to represent this part of the head with an enough clear drawing 2 . In this example the word 1 is presented here without the nominal prefix $A_{-}$. Later as a compound word: $\square$; (Urk. IV, 971, 5), and in Coptic: Makx "neck", Lacau, pp. 35-37 (\$§75 and 78).

${ }^{27}$ Depuydt, GM. 126, pp. 33, 36. For more discussions about the three names, see pp. 3338; Sethe, K., "Herbeibringen der Fähre", ss. 1-103; Krauss, Astronomische Pyramidentexte, ss. 67-86.
} 
All of the previous names of the celestial ferryman are connected with one meaning: it is about looking behind and facing backwards when he pays attention to the dead who summons him from his behind or this is his continual position and his perpetual state as he looks always towards his back to observe one who waits his return on the other side of the celestial waters to ferry him in his boat.

Also these names have expressive meanings of continuous waiting, observation and attention of this person and see how a ferryman stands in his boat.

Finally these names of the celestial ferryman are deeply connected with his role and linked to its importance in the Afterlife.

\section{7- $\mathrm{kn}$}

A name for the celestial ferryman without a certain sense from N.K. and Greco-Roman periods.

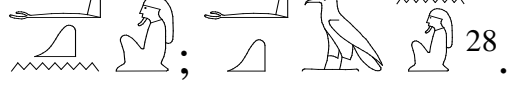

\section{8-` $k n-h ̣ r$}

A name of the celestial ferryman: ' $k n$ is a stem of unknown meaning. First attested in the Coffin Texts (M.K.), it is also attested in the Book of the Dead (N.K.) and at the temple of Edfu (Gr-rom. period).

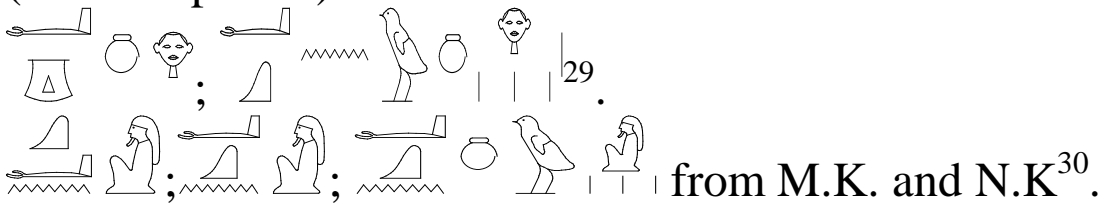

At the Temple of Edfu one of the crewmen of Re's boat is called:

' $k n-h r$ as a ferryman or a sailor:

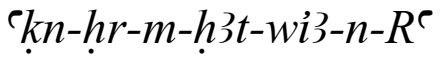

"kn-hr in the prow of Re's boat"

${ }^{28} \mathrm{~Wb}$ I, 235 (1).

${ }^{29}$ WPL. 183.

${ }^{30}$ LGG II, 237. 
M33- $h 3 . f$ "Who sees behind him" or the celestial ferryman is the boss of $~ k n$ and $~ " k n$ is the assistant of M33- h3.f who helps him for acting his profession when he turns his face backwards and commands him to come. ${ }^{~} k n$ is also a celestial ferryman ${ }^{32}$.

\section{9-Mhnty}

\section{With det. : "Ferryman, Boatman, Sailor",}

and with det. "Ferryman in the heaven, Celestial ferryman" from O.K. and M.K ${ }^{33}$.

This name is derived from verb ferry over water" from O.K., M.K., and N.K ${ }^{34}$.

$m \underline{h n t}$ "cross,

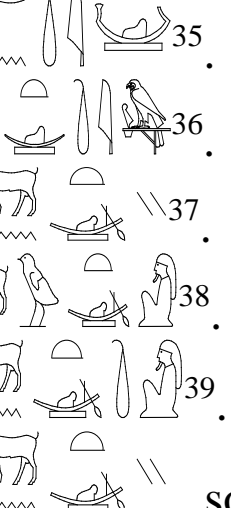

sometimes comes with the singular masculine definite article $p 3$ : $p 3$ Mhnty" The ferryman, The boatman" $(\text { N.K. })^{40}$.

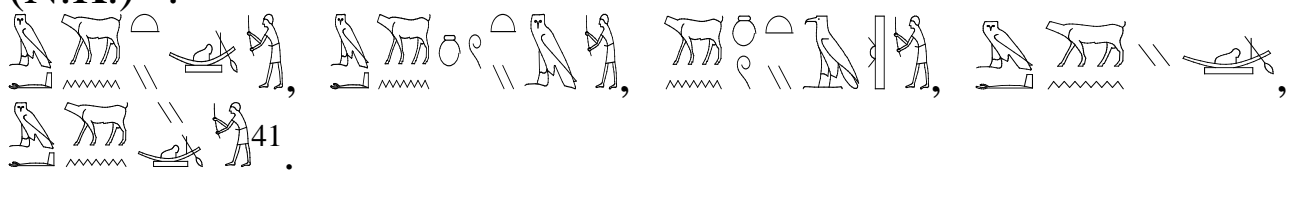

${ }^{31}$ LGG II, 237; EdfuVI, 150, 4-5.

${ }^{32}$ Sethe, ZÄS. 54, s.3 and note n. 1, for more discussions around $M 33-h 3 . f$ and ${ }^{\prime} k n$, see: ss. 2-13.

${ }^{33}$ Wb II, 133 (14-15); Van Voss, M.H., "Fähre" and "Fährmann", 85-86.

${ }^{34}$ Wb II, 133 (12-13); Rami van, D.-M., Dictionary of Coffin Texts, pp. 179-180.

${ }^{35}$ PT. 597.

${ }^{36}$ PT. 1193.

${ }^{37}$ Faulkner, Middle Egyptian, p. 115.

${ }^{38}$ CT III, 174.

${ }^{39}$ Urk V, 146, 17.

${ }^{40}$ LGG III, 396-397. 
Also $m$ m the previous verb ${ }^{42}$.

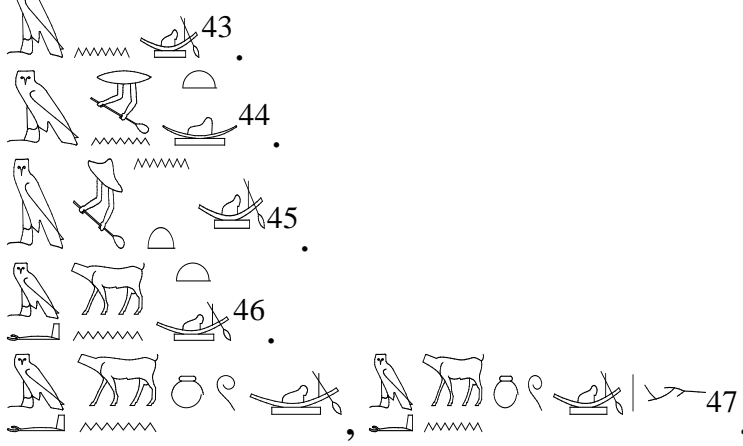

According to these writings we could observe clearly that the name of the ferryman Mhnty is formed by adding Nisbe-adjective (y) to the verb $m h n t$ "to ferry over water", or to the name derived from this verb: $m \underline{h} n t$ "ferry-boat".

Here we could give this name of the ferryman another related meaning: "He of the boat, he who belongs (relates) to the boat" by considering the name, and "He who ferries over water by a ferry-boat" by considering the verb.

These two explanatory meanings are so closed to his function and much suitable for the role he performs as he ferries people in his ferry-boat from a bank of a waterway to the other bank and he returns to carry out this action frequently.

This same role in life can be rightly applied to the importance of the ferryman's function in the hereafter according to the thoughts of ancient Egyptians about the Netherworld as will be discussed later.

${ }^{41}$ Lesko, L., Late Egyptian, I, p. 202.

${ }^{42}$ Gardiner, A., Egyptian Grammar, p. 612.

${ }^{43}$ PT. 334.

${ }^{44}$ PT. 384.

${ }^{45}$ PT. 494a; Sethe, ZÄS. 54, s.6 and note n. 4.

${ }^{46}$ Faulkner, Middle Egyptian, p. 115.

${ }^{47}$ Lesko, Late Egyptian, I, p. 202. 


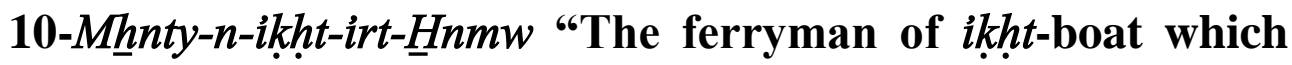
Khnum has made".

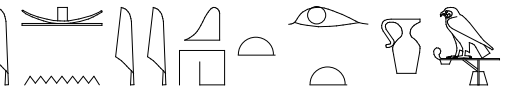

This name first occurred in the Pyramid Texts of O.K $\mathrm{K}^{48}$.

It is a descriptive name or title for the ferryman of the mythological place Nesat:

ferryman of $N s 3 t^{349}$.

\section{1-Mhnty-n-b3w-Iwnw "The ferryman of Iun-souls".}

A name of the ferryman in Heliopolis cult, mentioned in the Coffin Texts of M.K.

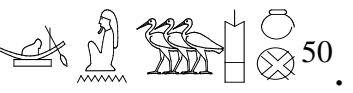

\section{2-Mhnty-pt "The ferryman of the heaven"}

\section{Also Mhnty-n-pt}

A name of the celestial ferryman, first attested in the Pyramid Texts, and occurring also in the Coffin Texts.

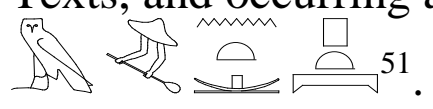

\section{3-Mhnty-Nwt "The celestial ferryman".}

This name is known from the Pyramid Texts.

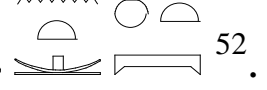

This name is dated to the Old Kingdom as mentioned in the Pyramid Texts.

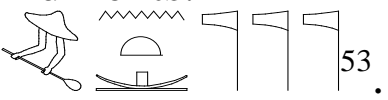

14-M $\underline{h} n t y-n-\underline{h} r t-n \underline{t} r$ "The ferryman of the necropolis". This name is dated to the Ramesside period (N.K.).

\footnotetext{
${ }^{48}$ PT. 445a; LGG III, 397.

${ }^{49}$ Kaplony, P., Rollsiegel Alten Reichs, II, p. 302 and plate 84; LGG VI,

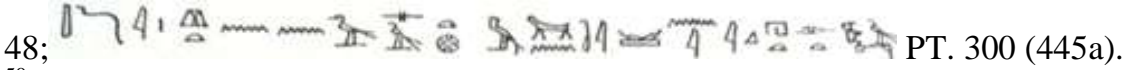

${ }^{50}$ CT V, 212b; 225b; LGG III, 397.

${ }^{51}$ PT. 383b; CT V. 178a; LGG III, 397.

${ }^{52}$ PT. 383b; LGG III, 397.

${ }^{53}$ PT. 383b.
} 


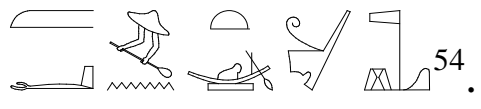

15-Mhnty- $n$-sht-ỉzrw "The ferryman of Iaru-fields".

This name is known from the Pyramid Texts (O.K.), the Coffin Texts (M.K.) and the Book of the Dead (N.K.) ${ }^{55}$.

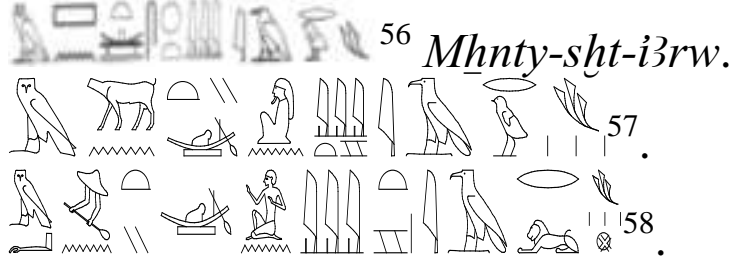

\section{6-Mhnty- $n$-sht-p3't "The ferryman of $p 3^{3} t$-fields".}

This name is first occurred in the Pyramid Texts (O.K.).

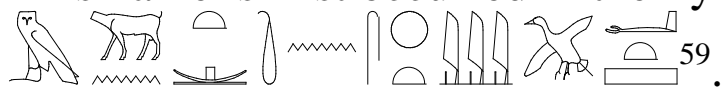

\section{7-Mhnty-n-sht-htpw "The ferryman of the field of offerings".}

This name is mentioned in the Pyramid Texts.

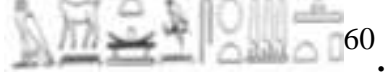

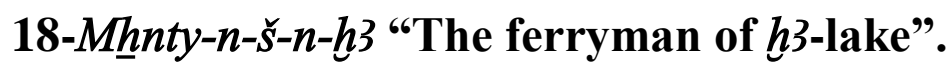

This name is attested in the Pyramid Texts (O.K.) and the Coffin Texts (M.K.) ${ }^{61}$.

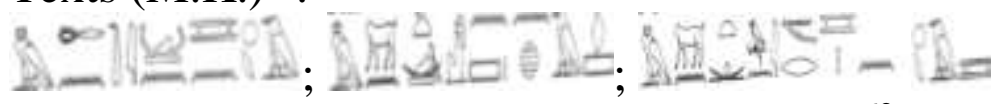

Mhnty-n- $\check{s}-n-h \underline{3}$ "The ferryman of $h 3$-canal" 62 .

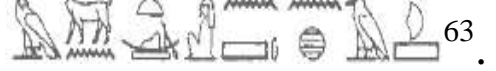

\section{9-Mhntyw-nw-Imntt "The ferrymen of the west".}

This name is found in the Coffin Texts (M.K.) ${ }^{64}$.

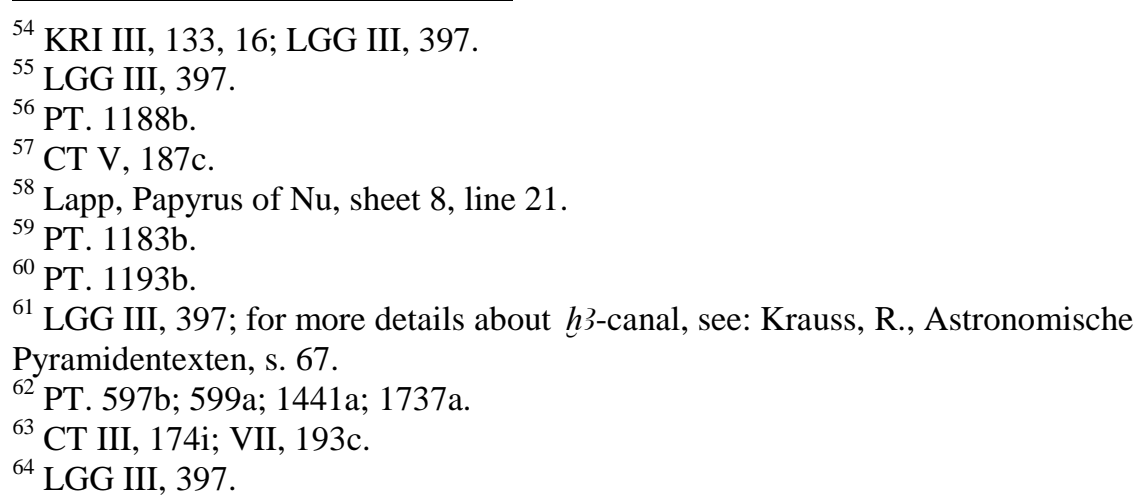




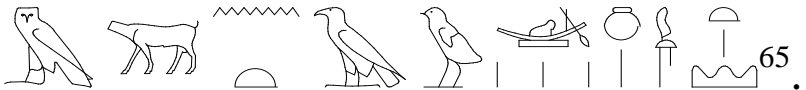

20- Mhntyw-nw-pt "The ferrymen of the heaven".

A name of the celestial ferrymen as it occurred in the Coffin Texts (M.K.) ${ }^{66}$.

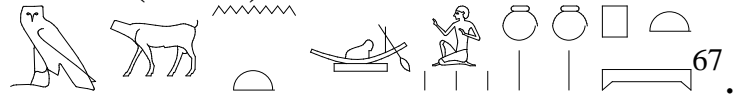

We could read about the celestial ferryman in the Pyramid Texts (the utterances from 594 to 946$)^{68}$.

\section{1-'Tw "The celestial ferryman"}

A synonym for the name Mhnty-n-sht-htpw "The ferryman of offering-fields" (name number: 17) ${ }^{69}$.

$(\mathrm{O} . \mathrm{K} .)^{70}$

$$
(\text { Gr.rom.) })^{71} \text {. }
$$

P3-iwy" The Crewman of a boat",

P3-iwy, he is the man who moves or operates part of the sailing tackle.

'Iwy may be connected with a piece of boat equipment called:

as mentioned in the Coffin Texts of M.K ${ }^{73}$.

At the temple of Edfu this name is mentioned also in the description of the festival of Hor-Behdety and the crewmen of his barque ${ }^{74}$.

${ }^{65} \mathrm{CT} \mathrm{V}, 170 \mathrm{~g}$.

${ }^{66}$ LGG III, 397.

${ }^{67} \mathrm{CT} \mathrm{V}, 170 \mathrm{~g}$.

${ }^{68}$ Sethe, ZÄS. 54, s.2.

${ }^{69}$ LGG I, 157.

${ }^{70}$ PT. 1193a.

${ }^{71}$ Ritter von Bergmann, E., Sarkophag des Panehemisis, ss. 11, 84; I. 1-40; II. 1-20.

${ }^{72} \mathrm{~Wb}$ I, 49 (21).

${ }^{73}$ WPL, 49; CT V, 191a; Faulkner, R. O., Coffin Texts, II, p. 52; Jones, D.A., Nautical Titles and Terms, p. 124.

${ }^{74}$ Edfu V, 126, 5; Alliot, M, ault d'Honus, II, p. 473. 
At the temple of Esna, Khnum-Re is titled sailor, the ferryman, the boatman" ${ }^{\text {"75 }}$.

Iwy "The

\section{III-Vocabularies of being without boat in the Hereafter}

Among the numerous and plentiful texts which were written in the pyramids of O.K., on the coffins of M.K., and in the Book of the Dead of N.K., there are some alterations of being in threat, danger and loss if one has no boat in the Netherworld by which to cross the celestial river:

$i w(y)$ "One without a boat"

If $I w^{77}$.

$i w i^{78}$.

its iwi, as an intransitive verb: "Be boatless"; and as a transitive verb: "Strand, leave boatless"

Kings pass this obstacle by accompanying the god $\mathrm{Re}$ in his morning-bark $M^{\top} n \underline{d} t$ and the evening-bark $M s k t t$, so under his protection they enjoy the eternal life and live in the eternity with everlasting residence in Iaru-fields under the supervision of Osiris according to the royal cult of Old Kingdom. In the Middle Kingdom this is completely changed when being safe in the Afterlife is connected with their good deeds, so the blessed dead could pass the obstacles and cross over dangers of the Netherworld by summoning the ferryman who ferries them the h3-canal to the Iaru-fields as mentioned above (see: names numbers: $12 ; 13 ; 15-21)$.

\footnotetext{
${ }^{75}$ Sauneron, S., Esna, II, p. 133, texte n. 58, line 3.

76 Gardiner, Egyptian Grammar, p. 552.

77 CT VI, 408 n, 775k; LGG I, 156.

78 PT. 117b; Budge, E.A.W., Book of the Dead, vol. I, text, pp. 261, 4; 281, 3.

${ }^{79}$ Faulkner, Middle Egyptian, p. 12.
} 


\section{V-Roles of $(H r . f-h 3 . f)$ in the Ancient Egyptian Religion \\ 1-The celestial ferryman (Sailor of the dead):}

Except his role as a celestial ferryman in the Underworld of the ancient Egyptians, $H r . f-h$. $f$ has played other different roles and performed distinguished duties through the religious thoughts in ancient Egypt.

\section{2-As genii in the Pyramid Texts:}

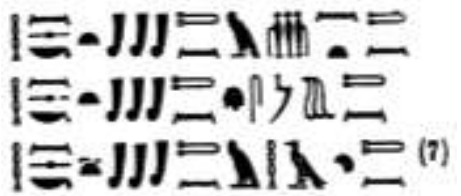

hnskwt.tn m-hnnt.tn

hnskwt.tn hr sm3.tn

hnskwt.tn $m$ - $h$ ? $3 . \underline{t n}$

Your locks upon your face

Your locks upon your temple

Your locks upon your neck ${ }^{80}$.

Here he is mentioned by his description not by his name $\mathrm{Hr}$. $f-h$ 3.f because he has two faces one in his front and the other is behind his neck ${ }^{81}$.

\section{3-As a demon of night terror:}

On an ostracon from Deir el-Medina of Ramesside date inscribed on both sides, now in the collection of the Ashmolean Museum of Oxford (H.O. 363) is a magical spell (Recto) against night terrors.

We read his name with the expression $m h r r h r$, understood as "being face forward "(Wb. III, 129, 14) rather than "from face to face". The demon would thus be depicted in characteristic posture, with his face twisted behind him (hr.f ḩ. f, Wb. III, 3; 914; CT., 473-480).

\footnotetext{
${ }^{80}$ PT. 1221; Lacau, Parties du Corps, p. 35.

${ }^{81}$ Depuydt, GM. 126, ss. 35-38; LGG V, 304; Hornung, E., Altägyptische Höllenvorstellungen, ss. 38-39; PT. 493b: a genii in the pyramid texts

\section{2. $\mathbf{1}$ -} front (before his head), and has a face in his neck (behind his head)".
} 
The Coffin Texts designations of the threatening demon of the net alternate between $H r . f-h 3 . f$ and $M 3-h 3 . f$, equating this fisherman with the Underworld ferryman.

Within the spells for escaping the net, the nuance of "Looking Behind" is perhaps emphasized for the benefit of the fleeing spirit, for when the spell commands the demon to look at the deceased (spell 479, in CT VI, 41a), he must turn his back to the soul, facilitating its escape ${ }^{82}$.

\section{4-As a protective divinity:}

In the papyrus of Nespeher ${ }^{\text {an }}$ from $21^{\text {st }}-22^{\text {nd }}$ dynasties found near Dêr el-Bahri in 1891 by Gaston Maspero.

Among 23 representations of divinities we see an illustration of a crocodile-headed divinity with an averted countenance, and named

Hr.f-n-h3.f. He must be the same being as Pyramid Texts ${ }^{8}$.

Hr.f-ḩ.f "turn-face", the celestial ferryman of the

\section{5-As the gate-keeper of Osiris:}

The gate-keepers of the abode of Osiris, which seems to have been a place of Embalming. This gives a special significance to passages like PT§1211a, where the ferryman is addressed as the "gate-keeper of Osiris" ${ }^{484}$.

\section{6-As one of the forty-two Assessors of the dead:}

This name is also given to the $27^{\text {th }}$ Assessor in ch. 125 of the Book of the Dead. In the papyrus of Nespeher'an:

"O Turn-Face, whose vision is taken away, the ba of the Osiris, the priest, scribe, oblationer of the House of Amun, beloved god's father of $M 3^{\top} t$, the daughter of $R^{\top}$, Nespeher'an, shall not be taken from the Eddy (bbt) of the west or from any waters of

\footnotetext{
${ }^{82}$ Ritner, R. K., "O. Gardiner 363“, pp. 25, 28 (D) and note (9), 28-30, M3- h3.f "Backward Looker", the underworld ferryman, p. 30 and note (15); WbIII, 913. See also: Bidoli, D., Die Sprühe der Fangnetze, ADAIK. 9, Gluckstadt, 1976, pp. 47-48; Kees, H., Toten Glauben, ss. 110-117.

${ }^{83}$ Blackman, A. M., “pap. Skrine, no. 2“, pp. 25, 28-29 (\$6, pl. III, bottom and pl. IV, top). ${ }^{84}$ Willems, The Coffin of HeQata, p. 176.
} 
the Field of Earu. He is $R^{\complement}$, who has come forth from the celestial cow $m h w$-wrt (great flood)" ${ }^{\$ 85}$.

In Ch. 306 in the scene of Judgment of the Dead and after the heart is weighed in the scales of the balance against the Feather of Righteousness and no sin was in the heart, the great ennead ordered Thoth to proclaim the innocence of the dead and let there, be given to him the offerings which are issued in the presence of Osiris, and a grant of land be established in the Field of Offerings as for the followers of Horus, and let there be given to him bread and beer which have been issued in the presence of Osiris, and he will be forever like the followers of Horus.

In spell 125 "The Negative Confessions" or "Declarations of Innocence" to the tribunal of forty-two gods (fig. 2 ) $^{86}$.

Among them the god number 27 is $H r . f-h 3 . f$ as a judge, the dead confess to him:

\section{$\mid$ IS:}

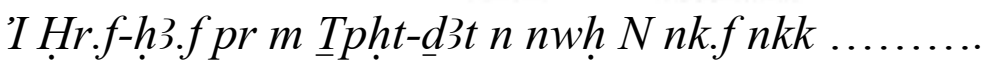

O, $H r . f-h 3 . f$ (who looks behind him) who comes forth from $\underline{T} p h t-$ $\underline{d} 3 t$ (Cavern of $\underline{d} 3 t$ at Memphis), N, didn't ...; he didn't practice sexual connection with a boy" 87 .

We read his name also as the judge $H r . f-h 3 . f$ of $\underline{T} p h t-\underline{d} 3 t$ on the sarcophagi of Wnnefer from Saqqara: the frieze of the east, the $2^{\text {nd }}$ register. He confesses to a person with a head of a rabbit turned backwards (fig.3):

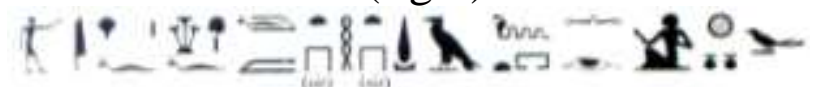

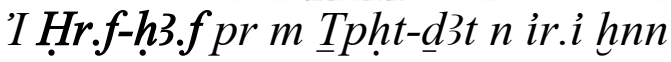

"O, Behind Looker who comes forth from $D 3 t$-Cavern, I didn't do a rebellion ${ }^{688}$.

\footnotetext{
${ }^{85}$ Blackman, Papyrus of Nespeher`an, pp. 28-29.

${ }^{86}$ Faulkner, R. O., Book of the Dead, pp. 27-29. See also: Faulkner, R. O. \& Others, The Egyptian Book of the Dead, The Book of Going Forth by Day, The Papyrus of ANI, San Francisco (1994).

${ }^{87}$ Moreet, A. et autres, Déclarations d'innocence, pp. 88-89, phrase 27.
} 
And in the Coffin Texts: "Hail, $H r . f-h 3 . f$, coming forth from the place of sailing, I have neither acted impurely, nor lain with men" 89 .

\section{VII-Texts of the Ferryman \\ I-Pyramid Texts}

We could read about the celestial journey of the dead king to the Afterlife in the texts of Unas pyramid ( $5^{\text {th }}$ Dynasty), utterance 263 , antechamber, south wall:

The king crosses over to the eastern sky in the sky's reed-floats

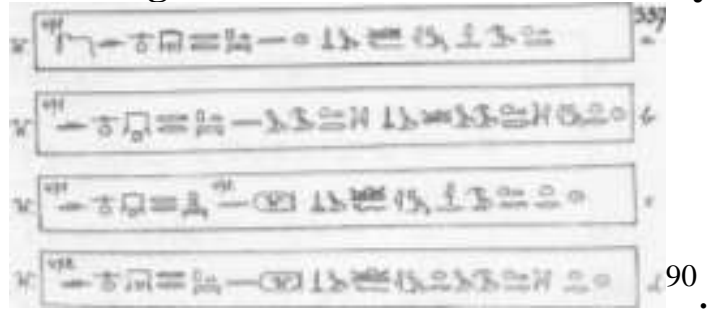

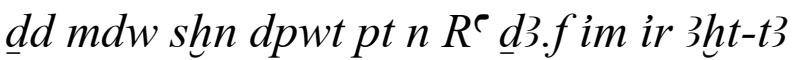

shnwt pt $n$ Hr-3hty d了 Hr-3hty im hr Re

shnwt pt $n$ (Wnis)| dis.fim ir 3 htt-t3 hr Re

shnwt pt $n$ (Wnis)| d3.fim hr Hr-3hty hr Re

* T: $=$ - wi:

w. 3.2

Nfrn (Wnis) $\mid h n^{\complement} k 3 . f^{\top} n h$ (Wnis)| hn $n^{\complement} k 3 . f$

3bi.f hr.f $3 m s . f m$ '. $f^{\top} b 3 . f m \underline{d}$ drt.f

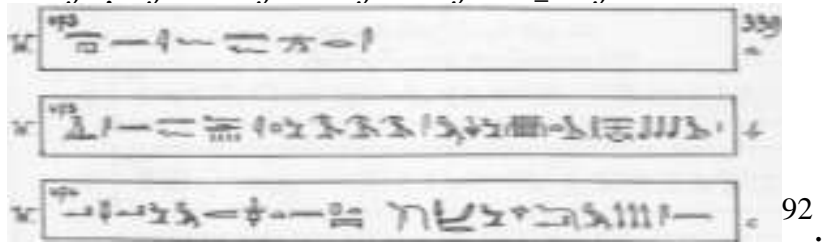

Nhn.f n.f is rsi

in.sn n.f fdw ipw 3hww smsw hntyw hnskwt

\footnotetext{
${ }^{88}$ Maspero, G. \& Gauthier, H., CG. N 29307-29323,tome II and plates XIII-XIV, pp.42, 49-50.

${ }^{89}$ CT II, 139f (117).

${ }^{90}$ Sethe, PT. I, 263 (337 a-d), s. 181.

${ }^{91}$ Sethe, PT. I, 263 (338 a-b), ss. 181-182.

${ }^{92}$ Sethe, PT. I, 263 (339 a-c), s. 182.
} 


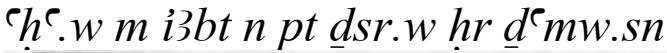

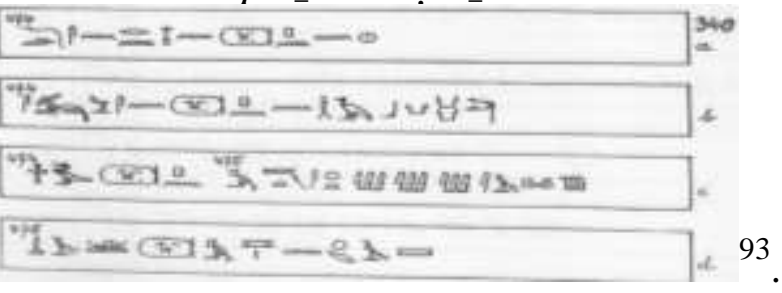

dd.sn rn $n f r$ (Wnis)|pn $n R^{e}$

siw.sn (Wnis)| pn n Nhb-k3w

ind ${ }^{\circ}$ (Wnis) $\mid$ pn mht shwt-ỉsw

$\underline{d}$ ) $(W n i s) \mid m \check{s}-n-h$ J

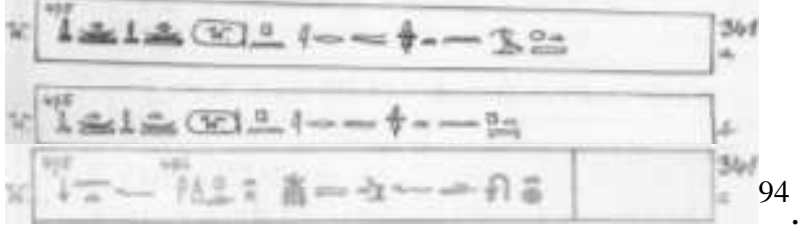

d3.t(w) $\underline{d} 3 . t(i)$ (Wnis)| pn ir i3bt n 3ht-t3

dj.t(w) $\underline{d}$ 3.t(i) (Wnis)| pn ir i3bt $n$ pt

snt.f Spdt mswt.f $d w 3 t$

The sky's reed-floats are launched for Re,

That he may cross on them to Lightland;

The sky's reed-floats are launched for Harakhty,

That Harakhty may cross on them to Re;

The sky's reed-floats are launched for Unas,

That he may cross on them to Lightland, to Re,

The sky's reed-floats are launched for Unas,

That he may cross on them to Harakhty, to Re.

It is well with Unas and his $\mathrm{Ka}$,

Unas shall live with his $\mathrm{Ka}$,

His panther skin is on him,

His staff in his arm, his scepter in his hand.

He subjects to himself those who have gone there,

They bring him those four elder spirits,

The chiefs of the side lock wearers,

${ }^{93}$ Sethe, PT. I, 263 (340 a-d), s. 182.

${ }^{94}$ Sethe, PT. I, 263 (341 a-c), ss. 182-183. 
Who stand on the eastern side of the sky

Leaning on their staffs,

That they may tell this Unas's good name to Re,

Announce this Unas to Nehebkau,

And greet the entry of this Unas.

Flooded are the Fields of Rushes

That Unas may cross on the Winding Water.

Ferried is this Unas to the eastern side of Lightland,

Ferried is this Unas to the eastern side of sky,

His sister is Sothis, his offspring the dawn ${ }^{95}$.

We read two of the celestial ferryman's names in utterance 310 (493b-494b):

\section{A summons to the ferryman of heaven to bring a boat to the king}

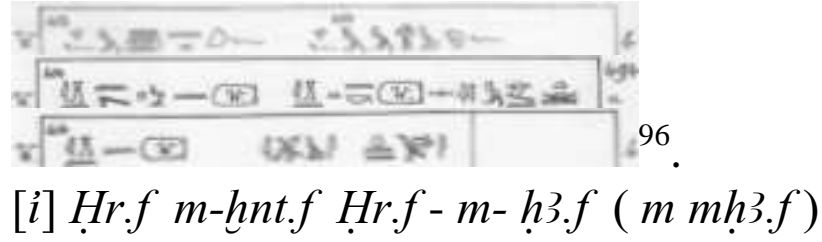

in $n w n(\quad)$

$\operatorname{in.t}(w) n . k(\quad) \mid s y$ mhnt

in $n(\quad)$ ipy.s hnn.s

$\mathrm{O}$ you whose vision is in his face and whose vision is in the back of his head, bring this to me!,

Which ferry-boat shall be brought to you?

Bring me "It-flies-and alight" "97"

The celestial ferryman also mentioned in utterance 359 (597a-c):

\footnotetext{
${ }^{95}$ Lichtheim, Ancient Egyptian Literature (1975), pp. 34-35; Faulkner, PT., pp. 72-73.And also in utterance 270 , on the same previous location, we read about the celestial ferryman" The king summons the ferryman": Sethe, PT. I, 270 (383 a-c), 384 a-b, 385 a-c, 386 a-b, 387 a-c, ss. 199-202; Lichtheim, Literature, pp. 35-36; Faulkner, R. O., Pyramid Texts, pp. 78-79; Mercer, A. B. S., Pyramid Texts, vol.1, pp. 91-92; Also in the pyramid texts of Pepi I $\left(6^{\text {th }}\right.$ Dynasty). In utterance 517 , passage to the antechamber, we read about the celestial boatman "The king addresses the ferryman": Sethe, PT. II, 517 (1188 a-f), 1189 a-f, 1190 a-c, 1191 a-c, 1192 a-b, ss. 162-166; Lichtheim, Literature, pp. 43-44.

${ }^{96}$ Sethe, K., Pyramidentexte, vol.1, 310 (493 b), (494 a-b), ss. 255-256.

${ }^{97}$ Faulkner, Pyramid Texts, p. 97; Mercer, Pyramid Texts, p. 106.
} 


\section{The king crosses to the beyond}

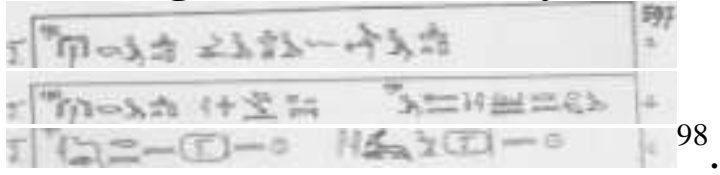

rs.k $m$ htp M3-ḩ.f $m$ htp

rs.k $m$ htp imy hnnwt $[m$ htp] mhnty $n \check{s}-n-h \underline{h}$

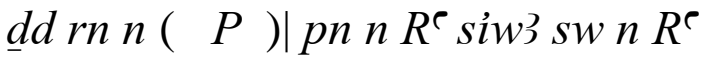

Awake in peace, O M3-h3.f, in peace!

Awake in peace, $O$ you who are in the sky, [in peace]!

O Ferryman of the Winding Waterway (lit. canal or river of $H_{3} 3$ ), Tell my name to $\mathrm{Re}$, announce me to $\mathrm{Re}^{99}$.

He is called "Bull of the gods" in the utterance 472 (925c-d) when the dead king summons him:

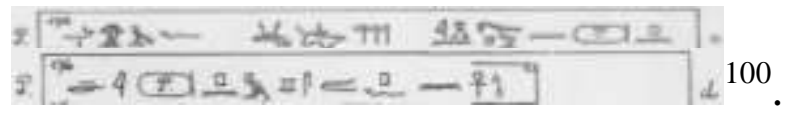

M3-ḩ.f k3-ntrw in nw n ( $P) \mid p n$

di $(N) \mid m$ gs $p f n{ }^{\top} n h$ w $w s$

O M3-h3.f, Bull of the gods, bring me this (= the ferry-boat) and set me on the yonder side of the lasting life (beyond) ${ }^{101}$.

Also Utterance 481(999-1001c) is:A summons to the ferryman

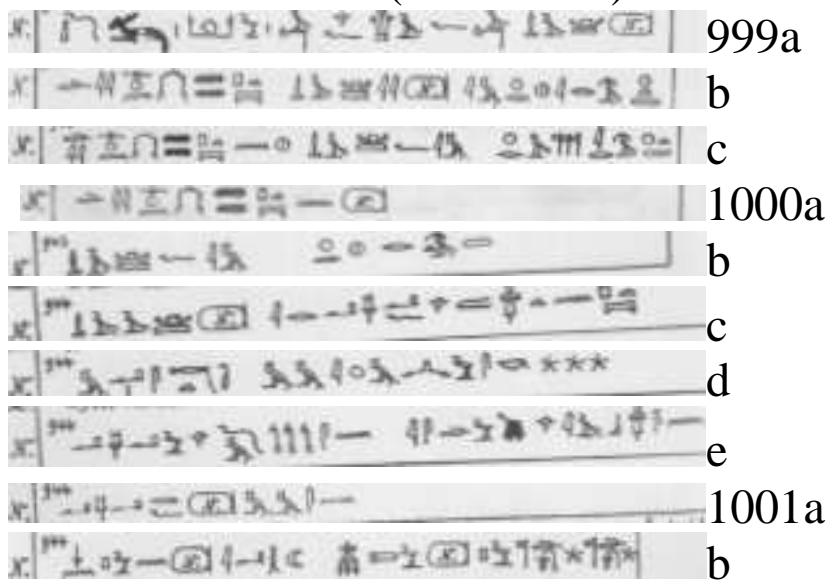

\footnotetext{
${ }^{98}$ Sethe, Pyramidentexte, vol.1, s. 319.

${ }^{99}$ Faulkner, Pyramid Texts, p. 116.

${ }^{100}$ Sethe, Pyramidentexte, vol.2, Leipzig (1910), s. 12.

${ }^{101}$ Faulkner, Pyramid Texts, p. 160.
} 
$\mathrm{f}^{\mathrm{A}} \mathrm{A}=-\mathrm{ar}^{4} \mathrm{c} \mathrm{c}^{102}$.

$\underline{d} d \mathrm{mdw}$ 'Iww Hr.f-ḩ.f $\underline{\mathrm{d}} 3$ ( N. ) |

dy shnty pt ( N. )| im hr Rer 3ht

dy shnty pt $n R^{e} \underline{d}$ 3. f im hr Hr $\mathrm{r}$ 3ht

d). f im hr Rer $3 h t$

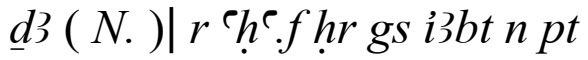

$m-{ }^{\circ} s(t) m-m$ ihmw-sk

'⿳⺈冂' $w$ hr $\underline{d}^{\top} m w . s n$ is $d w$ hr ỉbt.sn

¿⿳⺈冂r $r \dot{f} m-m . s n$

sn $p w n$ ( N. )| $\imath^{\top} h \operatorname{mswt}(N) \mid. p w n t r d w 3 w n t r d w 3 w$ di ${ }^{\top} . k r(N) \mid.\left[{ }^{\top} n h . f\right]$

Utterance: O 'Iww Hr.f-h3.f, ferry me across! The reed-floats of the sky are set in place, that I may cross by means of them to Re at the horizon.

The reed-floats of the sky are set in place for Re, that he may cross by means of them to Horus of the Gods at the horizon.

The reed-floats of the sky are set in place for me, that I may cross by means of them to $\mathrm{Re}$ at the horizon.

I ferry across in order that I may stand on the east side of the sky in its northern region among the Imperishable Stars, who stand at their staffs and sit(?) at their East; | I will stand among them, for the Moon is my brother, the Morning Star is my offspring; put your hand on me, [that I may live] ${ }^{103}$.

Another ferryman text could be read in utt. 505 (1091 a-1993 d):

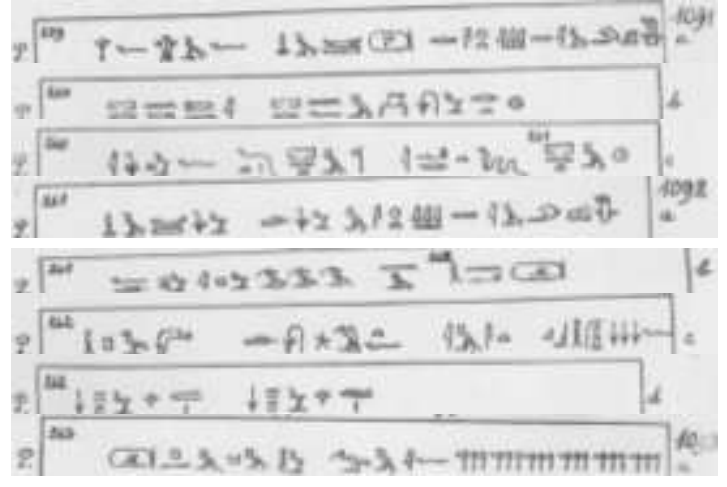

${ }^{102}$ Sethe, Pyramidentexte, vol.2, ss. 60-62.

${ }^{103}$ Faulkner, Pyramid Texts, p. 169; Mercer, Pyramid Texts, pp. 176-177. 


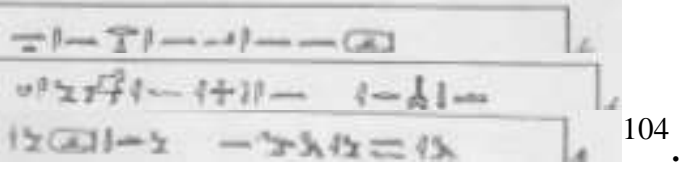

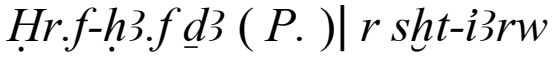

pr.n.k tni pr.n.f $m$ 3w3rt

iswt.f $\underline{d}$ t prt $m$ ntr $i^{e}$ rt prt $m R^{e}$

d) sw di sw m sht-i3rw

fdw ipw $3 h w(b 3 w) n 3 h n^{\complement}(M$.

HЗрi Dw3-mwt.f 'Imsti Kbh-snw.f

snw hr gs snw hr gs

prt pn $m$ hrmw gm.f ps $\underline{d t y}$ (2 ps $\underline{d} t)$

ntsn rdi.sn '.sn $n$ ( $M$. )

hms. fimy-tw.sn ir wd ${ }^{\top} m d w$

$w \underline{d}$ ( M. $) \mid m d w n$ gm iw.n.fim

O $H r . f-h 3 . f$, ferry me over to the Field of Rushes

Whence have you come?

I have come from $3 w 3 r t$, my companion(?) is the serpent which come forth the god, the uraeus which came forth from Re. Ferry me over and put me down at the Field of Rushes; these four spirits who are with me are Hapy, Duamūtef, Imsety, and Kebhsnuef, two on one side and two on the other. I I am the steering-oar; when I find the Two Enneads, they well give me their hands, and I will sit between them to give judgment; I will give orders to whomsoever I may have found there ${ }^{105}$.

The celestial ferryman Hr.f-hr.f is mentioned in the long utterance 519. We read about him particularly in $\S 1201 \mathrm{a}-\mathrm{d}$ of this utterance:

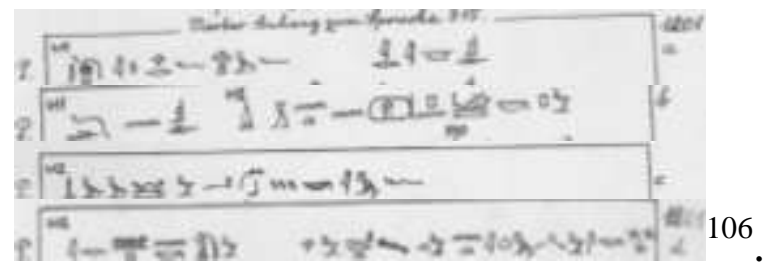

${ }^{104}$ Sethe, Pyramidentexte, vol.2, 505 (1091 a-c), 1092 a-d, 1093 a-e, ss. 104-106.

${ }^{105}$ Faulkner, Pyramid Texts, p. 181; Mercer, Pyramid Texts, p. 188.

${ }^{106}$ Sethe, Pyramidentexte, vol.2, ss. 171-172. 
dd mdw i Hr.f-ḩ.firy-e? Wsir

$\underline{d}$ d $n$ Wir di int $n$ ( P. )|pn dpt.kpw

d) w'bw.kim.f

$r \check{s} s p$ n.k kbhw hr w'rt tw nt ihmww-sk

O Hr.f-h3.f, gate-keeper of Osiris, say to Osiris: " Let me fetch for the king this boat of yours (= nšmt, bark of Osiris) in which your pure ones are ferried across in order to obtain for you the cold water at the (polar) quarter of the Imperishable Stars “6107.

In the next utterance 520, there is another ferryman text $(1222 \mathrm{a}$ 1223e):

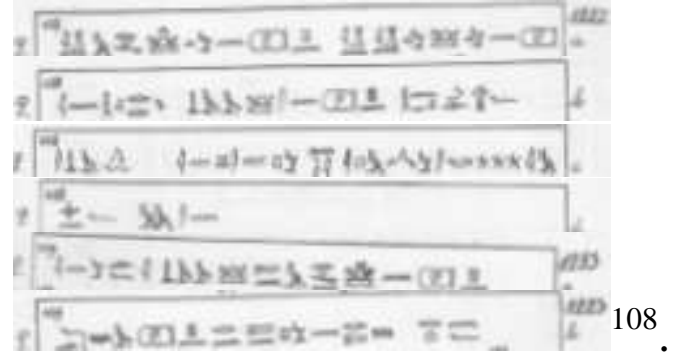

in $n(M) \mid$. mhnt tw in $n(M) \mid$. inwt tw

in Hkrr d3.sn (M. )| hnc M33-ḩ3.f

d) $(M) \mid. g s p w$ nty ihmw-sk im

wn (M. )| m-m.sn

ir wdf $\underline{d}$ 3.th $(M) \mid$.$m mhnt tw$

dd.k3.f rn.tn pw $n$ rmt $\underline{\text { nty }}$ ( $M$. $) \mid$ rh $n$ tmw

Bring me this ferry-boat; bring me this carrying-boat!

It is $H k r r$ who ferries them across <to> me in company with M33 $-h 3 . f$. I will across to that sides on which are the Imperishable Stars, that I may be among them. I If you delay to ferry me over in this ferry-boat, I will tell your names to men whom I know, to everyone $^{109}$.

We could read also a ferryman text in utt. 522 (1227a-d):

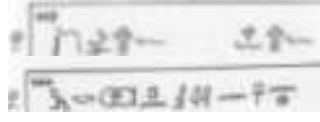

${ }^{107}$ Faulkner, Pyramid Texts, p. 192.

${ }^{108}$ Sethe, Pyramidentexte, vol.2, ss. 188-189.

${ }^{109}$ Faulkner, Pyramid Texts, p. 194; Mercer, Pyramid Texts, pp. 202-203. 


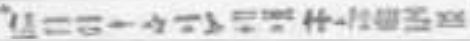

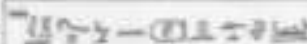

dd mdw M3-ḩ.f Hr.f-ḩ.f

$m k$ ( N. ) | pn ii $n$ ' $n h$

in.n.f n.k irt tw nt Hr tst imy sht- $\underline{h} n n w$

in $n w n(N) \mid$. pn irt $\underline{H} n m w$ mhnt

O M3-h 3.f, Hr.f-h3.f, behold, I have come and have brought to you this re-knit Eye of Horus which was in the Field of Strife; bring me this boat which Khnum built ${ }^{111}$.

In utt. 569 (1441a-c):

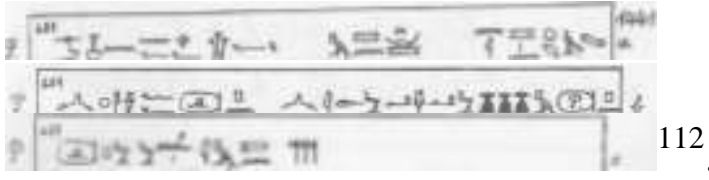

smn.n.f Hr.f-ḩ3.f mhnty $n \check{s}-n-h$ J

$n$ hsff (M. )|pn n irw ${ }^{\complement} h^{\complement} w$ sdbw m ( P. )|pn

(M. ) $\mid p w w^{\complement}$ im.tn $n \underline{t r} w$

$H r . f-h$ J. $f$ has made ready for me, (even he) the ferryman of the Winding Waterway. I will not be held back, nor will obstacles be set against me, for I am one of you, you gods ${ }^{113}$.

And in utt. 625 (1769 a-c):

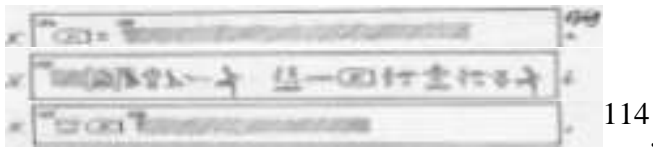

$(N) \mid. p[n]$

[i] M3-h3.f in $n(N) \mid$. Kd htp irt $\underline{H}$ nmw

$\operatorname{pr}(N) \mid$.

${ }^{110}$ Sethe, Pyramidentexte, vol.2, s. 192.

${ }^{111}$ Faulkner, Pyramid Texts, p. 195; Mercer, Pyramid Texts, pp. 203.

112 Sethe, Pyramidentexte, vol.2, s. 284.

${ }^{113}$ Faulkner, Pyramid Texts, pp. 222-223. For more details around $\check{s}-n$ - $h$ 3 “ $h$ h-canal “ (Celestial Winding Waterway) linked with the celestial ferryman, see: Krauss, R., Astronomische Konzepte und Jenseitsvorstellungen in den Pyramidentexten, Ä A.59, Wiesbaden, 1997, pp . 67-85.

${ }^{114}$ Sethe, Pyramidentexte, vol.2, s. 426. 
[Ho!] Who-sees-behind-him, bring to $N$. the $k d-h t p$ (a name of a ferry-boat), made by Khnum, That $\mathrm{N}$. may ascend 115

\section{II-Coffin Texts}

As we discussed above, the PT mentioned two names of the celestial ferryman: $M 3-h 3 . f$ and $H r . f-h 3 . f$.

But the CT mentioned three names: Hr.f-h3.f, M3-h3.f for the celestial ferryman and $\mathrm{k} n$ for his assistant.

We read their names together in the same one text, firstly, the name of the celestial ferryman, and then, fellow with the name of his assistant ferryman $\mathrm{r} k n$ as we will see below in the next pages.

In spell 117, we read his name Hr.f-h3.f (fig.3 for the original hieroglyphic text) ${ }^{116}$ :

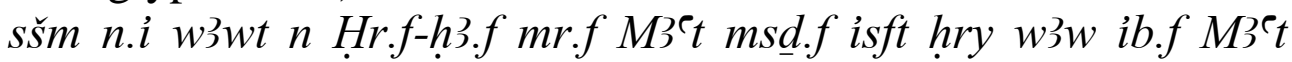
š̌mw n(.i) ntriw hr.s

Control for me the paths of His-face-is-behind him, | who loves truth and hates falsehood, who is over the broodings (?) of his heart (and of (?)) Māre t, because of whom the gods are guided to $<$ me $($ ? $)>^{117}$.

The same name is mentioned in spell 214 (fig.4 for the text) ${ }^{118}$ :

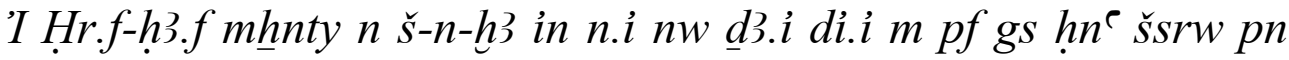
ntyw $m$ r.i $\underline{d} r$-ntt.i hpr rk.i m ntr

O Hr.f-ḩ.f, ferryman of the Winding Waterway, bring me this, ferry me across and set me on yonder side with these bags which are in my hand, because I am become a god ${ }^{119}$.

The name $M 3-h 3 . f$ is mentioned in spell 343 (fig.5 for the text) ${ }^{120}$ : nis.k3.<k>rf ntr $p w r . k h^{\ulcorner} R^{\top} m$ b3.f hr nis.k r.k r M3-h3.f

\footnotetext{
${ }^{144}$ Mercer, Pyramid Texts, pp. 267-268; Faulkner, Pyramid Texts, p. 259, and note n. 9. for further readings about the ferryman in the PTs, see also: J. Ogdon, The Celestial Ferryman in the Pyramid Texts, vol. 2, Buenos Aires (1977).

${ }^{116}$ De Buck, A., Coffin Texts, II, pp. 138 (spell 117f), 139(117a-b).

${ }^{117}$ Faulkner, R.O., Coffin Texts, I, pp. 109-110.

${ }^{118}$ De Buck, Coffin Texts, III, p. 174 (spell 214i-1).

${ }^{119}$ Faulkner, Coffin Texts, I, p. 171(spell 114).

${ }^{120}$ De Buck, Coffin Texts, IV, p. 359 (spell 343c-e).
} 
You shall summon this god to you when Re appears with his soul, you shall summon to you the celestial ferryman ${ }^{121}$.

The assistant of the ferryman ( $\left.{ }^{\mathrm{k} n} \mathrm{n}\right)$ is mentioned also in spell 343 (fig.6 for the text) ${ }^{122}$ :

rs $n . k$ ' $k n$ in $n t f n . k$ mhnt tw $\underline{d} 3 . t(i) b 3 w$ - ${ }^{-p}$ rw im $s(t)$

Awaken 'Aken, that he may bring to you that ferry-boat in which the equipped spirits ferry across ${ }^{123}$.

In spell 344, the ferryman and his assistant were mentioned, the two both together (fig.7 for the text) ${ }^{124}$ :

nis.k3.i r M3-h3.f rs.k3.f 'kn in.k3.f n.i mhnt b3 ' $p r(. t i) ~ ' p r$ wi im $s(t)$

I will summon the celestial ferryman, and he will wake 'Aken, he will bring me the ferry-boat. O equipped spirit, equip me in it ${ }^{125}$. Spells from 395-398 are circulating around a similar or a repeated long questionary dialogue among the deceased and the ferryman and his assistant $\mathrm{kn}$ in order to allow to him to ferry the Winding Waterway and cross in his ferry-boat ${ }^{126}$.

In spell 400 the deceased demands from the ferryman $M 3-h 3 . f$ to bring him a boat called $k 3 y t$ "the high" (fig. 8 for the text) ${ }^{127}$ :

M3-h3.f mi in n.i mhnt rn.s n k3yt m 3h.s n k3yt

$\mathrm{O}$ Mahaf, come and bring me the ferry-boat in its name of $k 3 y t$ boat and in its power of $k 3 y t$-boat ${ }^{128}$.

And in spell 401(fig.9 for the text) ${ }^{129}$ :

r3-n mhnt $i 3 h w 7$ ipw m mhnty Imntt in n.i mhnt tw iw wi rh.n.i tn $r$ rh .n.i rn.tn M3-3ht-n.f in n.i mhnt tw $m$ [rn.s n kjyt $m]$ 3h.s $n k 3 y t[\ldots . .$.$] h3i.i im r'Imnt ph.i nt$

\footnotetext{
${ }^{121}$ Faulkner, Coffin Texts, I, p. 279 (note 21).

${ }^{122}$ De Buck, Coffin Texts, IV, p. 360 (spell 343 a-b).

${ }^{123}$ Faulkner, Coffin Texts, I, pp. 277-279(spell 343).

${ }^{124}$ De Buck, Coffin Texts, IV, p. 367 (spell 344e-h).

${ }^{125}$ Faulkner, Coffin Texts, I, pp. 279-280 (spell 344).

${ }^{126}$ De Buck, Coffin Texts, V, p. 73 (spell 395a-c); sp. 396d-o; p. 74, sp. 396a-z; aa-cc; p.

77, sp. 397a-c; p. 79, sp. 397a-c; Faulkner, Coffin Texts, II, sp. 395, pp. 20-22; sp. 396, pp.22-24; sp. 397, pp. 24-33; sp. 398, pp. 33-43.

${ }^{127}$ De Buck, Coffin Texts, V, p. 171 (sp. 400a-f).

${ }^{128}$ Faulkner, Coffin Texts, II, pp. 43-45 (sp. 400).

${ }^{129}$ De Buck, Coffin Texts, V, p. 174 (sp. 401a-k).
} 
Spell for a ferry-boat. O you [seven (?)] spirit, ferryman [of] the West, bring me the ferry-boat when I call out, [because (?)] I know you and I know your names. O M3-3ht- $n$.f, bring me the ferry-boat in [its name of $k 3 y t$-boat and in] its power of $k 3 y t$-boat [...... I will go down in it to the West, I will reach the god who is in (?) $[\ldots . . .]^{130}$.

In the long spell 474 the ferryman $M 3-h 3 . f$ "who look backward" is called: the aggressive fisherman who fishes with the spear and fish-trap. The deceased hopes to be not catch or trapped in his net $^{131}$.

The same meanings can be understood in spells $475-480^{132}$.

Mueller has dealt with the ships of the Underworld and its skipper, parts and calling the ferryman of the Field of Reeds as it mentioned in the Coffin Texts (Sps. 404/405) in the $3^{\text {rd }}$ version of CT from El- Bersheh, and other points connected with the Hereafter of the ancient Egyptians. He has divided his article in JEA.58 (1972) in a good and clear guideline for the texts, translations, notes, comments and explanations ${ }^{133}$.

Willems has studied the ferryman spell (CT 398) in details even its tiny parts as it inscribed on the Coffin of Heqata (OLA.70, 1996).

This text consists of 3 parts:

The introduction: CT. V, 120a-124.

The list of ship's parts: CT. V, 125a-149c.

And the conclusion: CT. V, 150a-160c.

We could consider it as a complete model and the ideal of ferryman spells in the ancient Egyptian texts of Afterlife.

${ }^{130}$ Faulkner, Coffin Texts, II, pp. 45-46 (sp. 401). The ferry-boat is mentioned also in spells 402, 403, and 775 .

${ }^{131}$ De Buck, Coffin Texts, VI, pp. 17-26; Faulkner, Coffin Texts, II, pp. 112-116 (sp. 474).

${ }^{132}$ De Buck, Coffin Texts, VI, pp. 27-45; Faulkner, Coffin Texts, II, pp. 116-126 (sps. 475480).

${ }^{133}$ Mueller, D., "Guide to the Hereafter", pp. 104-125. 
The spell 398 is more than a dramatic account of events the deceased might expect in the divine world; the interaction in the text may well reflect ritual activity.

Spell 398 may accordingly envisage a situation in which the ferryman, who lives in the Heliopolitan area, crosses the Winding Waterway to fetch the deceased, and to bring him to their home town.

The dialogue of the introduction can be summarized as follows: The deceased addresses a ferryman with a florid request that the ship may be brought.

The ferryman first wants to know the identity of his passenger. The latter replies that he is "one whom his father loves", to which he adds, in reaction to a second question, that this is so because of a number of acts he has carried out for his father. All of these are of a ritual nature.

The deceased repeats his request that the vessel be prepared. The ferryman protests that it has not even been "hollowed out" yet, which probably means that it has not progressed beyond an incipient stage of construction.

The introduction ends with the deceased's impatient request that the boat be constructed with the assistance of Sokar. The deceased opens his speech with a series of epithets of the ferryman, these describe him as "one who brings Horus to his eye, who brings Seth to his testicles, and who brings the bark to Horus when it flees and falls down to his garden, it being saved from the hand of Seth".

At the end or conclusion of the spell, even thus for the deceased has borne testimony to his encompassing knowledge, his ordeal is not yet over.

Before he will finally be allowed to enter the ferry, he must produce satisfactory replies to a series of additional questions.

In the ferryman spells, the deceased has reached the bank of the Winding Waterway, which he intends to cross by ferry. The river is one symbolic interpretation of the "luminal area of ordeal" to be passed by the deceased, an ordeal which could alternatively 
take the form of an encounter with the celestial fisherman, or with the divine tribunal.

Spell 398 specifies that the deceased gathers the required amount of emmer and barley to make an invocation offering from it to the seven deities, an activity was displayed in the Field of Reeds, thus after the crossing of the Winding Waterway.

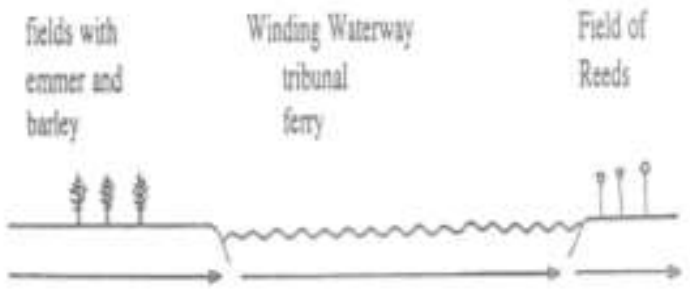

The topography of the Netherworld according to CT V, 153a-c [398]. The deceased deals with agricultural activity performed prior to the moment when the Winding Waterway was reached. He now orders (the ferryman) that the ferry be brought and enjoins the deceased to enter it.

At last, the ferrymen give the deceased permission to proceed. He also mentions the acme he inspires in the gods, who welcome him as "an equipped spirit". He next invites the gods of the four cardinal points to come and see him wearing $m \underline{d} h$-fillet and an ' $f$-headcloth. The ferrymen are ordered to make the crossing.

The final lines of the texts elaborate on the theme of the deceased's sovereignty. It is an address to the goddess Hathor, who is asked to draw the deceased to the sky.

As a result of this, he expects to sit among the great gods as a judge, to pronounce Ma'at, and to restrain the humans ${ }^{134}$.

The first part of spell 343 (CT. IV, 343b-e; 344f-m, p. 359-367) was inscribed on the back surface of the coffin of lady Ouadj (Sid 2 Sid) found in the cemetery of Sedment (1992-1993), the ancient necropolice of Herkleopolis Magna (Ihnasya elMedinam, Beni-Seuif).

On this part of Ouadj's coffin (cols. 14-21), (fig. 10 for the text):

${ }^{134}$ Willems, H., Coffin of HeQata, pp. 156-173. 


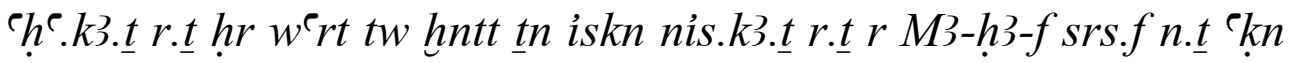
int.f n.t m $\underline{h} n t$ tw $\underline{d} 333 \mathrm{~h} w$ ' $\mathrm{pr} w$

You will stand to you in this region in the upper of Iskn and you will summon to you M3- $h 3-f$ "Who-sees-behind-him", who will wake to you $\ulcorner k n$ to bring to you this boat in which the equipped souls cross ${ }^{135}$.

The previous discussed PTs and CTs have shown to us the meanings of the names of the celestial ferryman, his context and what his role was.

\section{Conclusion}

1-In the Underworld there were many lakes in which the deceased had to purify himself, many canals and river-branches to be crossed. Since he possessed no boat of his own (a threat and lost for him), it was necessary for him to summon a ferryman at each crossing, naturally by means of a magic formula, in which the mystic name of the ferryman was contained.

2-The Egyptian ferryman is an important personality (god) figures to mention in the Afterworld that he would navigate the soul through the winding waters of the Underworld.

3-The so-called Egyptian ferryman is known from the funerary texts: Pyramid Texts of the Old Kingdom, Coffin Texts from the Middle Kingdom, Book of Dead from the New Kingdom and texts of the Greco-roman hieroglyphs.

in about 21 names and titles

4-The ferryman $~ k k n$ of the dead is the sailor who carries the souls of the dead in his little papyrus boat with a single oar. He spends most of his time sleeping at his oar. Whenever a soul comes along asking for passage, they have a terrible time trying to wake him up ( ${ }^{\mathrm{k} n} \mathrm{n}$, he is the assistant of the main celestial ferryman M33-ḩ.f).

5-The ferryman of the Otherworld loved truth and hated sin, and because of his integrity, became a leader of the gods.

${ }^{135}$ Abdel Fatah (Ahmed Galal) \& Bickel (Susanne), "Trois Cercueils de Sedment “, pp. 1, $3,5,8$, fig. 1 et photos 3,6 . 
In the Negative Confessions (BD, chapter 125; CT II. 138f [117]), the deceased addressed a series of two and forty gods by their names one after the other, and asserted before each, that he had not committed a certain sin. Among these two forty gods is the ferryman of Underworld (God number 27 as a judge) whose name $H r-f-h 3 . f$ (see names numbers: 3-5).

6-Hrty is a more ambiguous deity who was considered to be a god of the Underworld and the ferryman of the dead (see name number: 10).

7- ${ }^{-k n}$ (see names numbers: 7,8 ) is often associated with Hrty (Kherty also spelt Cherti), and it is considered a possibility that his cult caused the development of the myth of the ferryman in other Mediterranean mythologies, such as that of Greek Charon. In any case, though we have seen that the Egyptians had their ferryman among their gods, this is not related to the ferryman Charon of the Greeks. Both cultures developed naval technologies independently, and water (the sea, rivers) was simply an important part of their civilizations. These ferrymen developed independently.

8-The idea of the ferryman of Netherworld is not found in ancient Egypt and Greece only, but also found in other ancient cultures as in Yorubas of south Nigeria, Mesopotamia, Ancient Europe, Greece, Rome, and Norse (Bronze-Age of Denmark) 


\section{List of Abbreviations}

\section{I- Periodicals:}

ÄA

Ägyptologische Abhandlungen, Wiesbaden.

BIFAO Bulletin de L'Institut François d'Archéologie Orientale, Le Caire.

BdE Bibliotheque d'Etude. IFAO ( Le Caire).

GM Göttinger Miszellen, Beiträge Zur Ägyptologischen Diskussion, Gottingen.

JARCE Journal of the American Research center in Egypt, (Boston, New York).

JEA Journal of Egyptian Archaeology. Egypt Exploration Society, London.

OLA Orientalia Lovaniensia Analecta, Leuven.

RAPh Recherches d'Archéologie, de Philology et d'Histoire. Inst. Franç. d'archéol. Orient. (Le Caire).

SAK Studien Zur Altägyptischen Kultur ,Hamburg.

ZÄS Zeitschrift Für Ägyptische Sprache und Altertumskunde, (Leipzig,

Berlin).

II- Books:

CG = CGC Catalogue Général des Antiquités Égyptiennes du Musée du Caire, le Caire.

CT De Buch, A., The Egyptian coffin texts 7vols, Chicago, Illinois (1935-

1961); Faulkner, R. O., The Ancient Egyptian coffin texts , 3 vols., Warminster (19731978).

Edfu Chassinant, E., Le Temple d'Edfou, vols1-14, Le Caire (1897-1934)

(Vol.1 avec Rochemonteix), 2nd edition by Cauville, S., Le Caire (1984-1987).

KRI Kitchen, K. A., Ramesside Inscription, Oxford.

LGG Leitz, Ch., Lexikon der ägyptischen Götter und Götter bezeichnugen, 8 Bde, OlA.110-129(2002-2003).

$\mathbf{P T}=\mathbf{P y r} \quad$ Sethe, K., Die Altaegyptischen pyramidentexte nach den Papier Abdrüken und Photographien des Berliner Museums, 4 Bde, Leipzig (1908-1922); Mercer, S. A. B.,The pyramid Texts, vols. 1-4, NewYork (1952); Faulkner, R. O.,The Ancient Egyptian pyramid Texts, Oxford, (1962).

Urk Urkunden des Ägyptischen Altertums, I-VIII, Berlin \& Leipzig (19041957).

Wb Erman, A. \& Grapow, H., Wörterbuch der Ägyptischen Sprache, 7 Bde, Leipzig (1971), Berlin (1982).

WPL Wilson, P., A Ptolemaic Lexikon, A lexicographical study of the Texts in the Temple of Edfu, OLA. 78 (1997).

Bibliography

Abdel Fatah (Ahmed Galal) \& Bickel (Susanne), "Trois Cercueils de Sedment", in: BIFAO. 100, IFAO, Le Caire (2000), pp. 1- 36.

Alliot, M., Le cult d'Horus à Edfou au temps de Ptolémées, Bde.20 (1-2), Le Caire (1979).

Bidoli, D., Die Sprühe der Fangnetze, ADAIK. 9, Gluckstadt (1976).

Blackman, A. M., "The Funeary Papyrus of Nespeher'an (pap. Skrine, no. 2)“, in: JEA. 5 (1918), pp. 24-35.

Budge, E.A.W., The Book of the Dead, vol. I, text, London, 1898.

Buhl, M.-L., The Late Egyptian Anthropoid Stone Sarcophagi, Kopenhagen, 1959.

Chassinat, É., Le Temple D' Edfou, 15 vols., Ifao, Le Caire, I ${ }^{\mathrm{I}-\mathrm{IV}}$ avec le marquise de Rochemonteix (1984-1987), II ${ }^{1-2}$ (1987-1990), III (1928), IV (1929), V (1930), VI (1931),

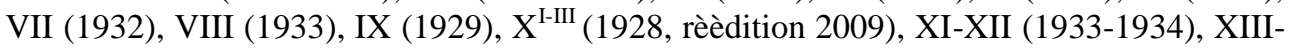
XIV (1934); Deuxième edition revue et corrigèe par Sylvie Cauville et Didier Devauchelle: XV, Ifao, Le Caire, (1985).

De Buck, A., The Egyptian Coffin Texts, vols. I-VII, the University of Chicago press, 
Chicago (1935-1961).

Depuydt, L., "Der Fall des "Hintersichschauers", in: GM. 126 (1992), p.33-38.

Edel, E., Alt Ägyptische Grammatik, Ialy (1955-1964).

Faulkner, R.O., An Ancient Book of Horus (Papyrus British Museum 10569), Oxford, 1958.

pp. 66-74. "Giessen University Library Papyrus No. 115", in: JEA. 44 (Dec. 1958), , A Concise Dictionary of Middle Egyptian, Oxford, 1964. , The Ancient Egyptian Pyramid Texts, Oxford (1969). , The Ancient Egyptian Book of the Dead (Andrews Carol, ed.), University of Texas Press (1990). \& Others, The Egyptian Book of the Dead, The Book of Going Forth By Day, The Papyrus of ANI, San Francisco (1994).

III, 1978). The Ancient Egyptian Coffin Texts, 3 vols., England (I, 1973, II, 1977,

Gardiner, A., Egyptian Grammar, $3^{\text {rd }}$ edition, revised, Oxford, 1949.

Hornung, E., Altägyptische Höllenvorstellungen, Akademie-Verlage-Berlin, 1968.

Jones, D.A., Glossary of Ancient Egyptian Nautical Titles and Terms, London, New York, 1988.

Kaplony, P., Die Rollsiegel des Alten Reichs, II, Katalog der Rollsiegel, 2 Bde, MA.3, Bruxelles, 1981.

Kees, H., Toten Glauben und Jenseitsvorstellungen der Alten Ägypter, Grundlagen und Entwicklung bis zum Ende des Mittleren Reiches, Leipzig, 1926.

Koefed-Petersen, O., Catalogue des Sarcophages et Cercueils Égyptien, Copenhague, 1951.

Krauss, R., Astronomische Konzepte und Jenseitsvorstellungen in den Pyramidentexten, Ä A.59, Harras Owitz Verlag. Wiesbaden, 1997, ss. 67-85.

Lacau, M., Les Nomes des Parties du Corps en Égyptien et en Sémitique, Paris (1970).

Lapp, G., Catalogue of Books of the Dead in the British Museum, I, The Papyrus of Nu (BM E 10477), London, 1997.

, "The Papyrus of Nu", in: JEA. 89 (2003), PP. 263-264.

Lesko, L., Late Egyptian Dictionary, $2^{\text {nd }}$ edition, Vol.1, Providence, 2002 (pdf copy).

Lichtheim, M., Ancient Egyptian Literature, vol. 1, the Old and Middle Kingdoms, Los Angeles, Near Eastern Center, California, 1975.

Louise, G., Die "Textschmiede" Theban- Der Thebanische Beitrag zu Konzeption und Tradierung von Sargtexten und Totenbuch", in: SAK. 25 (1998), ss. 83-99.

Lurker, M., Götter und Symbole Der Alten Ägypter, Ginführung und kleines lexicon, Otto Wilhelm. Barth Verlag, ss. 180-181.

Maspero, G., Sarcophages d' Époque Persane et Ptolémaïque, CG 29305, Le Caire, 19081914.

Maspero, G. \& Gauthier, H., CG. N 29307-29323. Sarcophages des Époques Persane et ptolémaïque, IFAO, LE Caire (1939).

Mercer, A. B. S., The Pyramid Texts, in translation and commentary, vols. I-IV, New york, London, Toronto (1952).

Moreet, A. et autres, Les Déclarations d'innocence (Livre des Morts, Chap. 125), RAPh. 8, Paris (1934) et Le Caire (1937).

Mueller, D., “ An Early Egyptian Guide to the Hereafter “, in: JEA. 58 (1972), pp. 99- 125. Ogdon, E.J. The Celestial Ferryman in the Pyramid Texts, vol. 2, Buenos Aires (1977). 
Francisco, 1994.

The Egyptian Book of the Dead: The Book of Going Forth by Day, San

Rami van, D.-M., A Hieroglyphic Dictionary of Egyptian Coffin Texts, Probleme Der Ägyptologie. 15, Brill (Leiden.Boston.Köln), 2000.

Richard H. W. , The Complete Gods and Goddesses of Ancient Egypt, Thames and Hudson, New York (2003).

Ritner, R. K., “O. Gardiner 363: A Spell Against Night Terrors 1“, in: JARCE. 27 (1990), pp. 25-24.

Ritter von Bergmann, E., Der Sarkophag des Panehemisis, Historischen Sammlungen des Österreichen Kaiserhauses, 1883.

Sauneron, S., Le Temple d'Esna, 8vols, Ifao, Le Caire (I,1959, II, 1963, III, 1968, IV, 1969, V, 1962, $\mathrm{VI}^{-1}, 1975$, VIII avec une note de J. J. Clère,1982), vol. VII textes édités par Jochen Hallof, Ifao, Le Caire (2009).

Sethe, K., Die Altaegyptischen Pyramidentexte, vols. I-IV, Leipzig (1908-1922).

, "Zur Komposition des Totenbuch Spruches Für das Herbeibringen der Fähre (Kap.99 Einleitung)", in: ZÄS. 54 (1918), pp. 1-103.

Speleers, I., Recueil des Inscriptions Égyptiennes des Musées Royaux du Cinquantenaire á Bruxelles, 1923.

Taylor, J., Death and the Afterlife in Ancient Egypt, University of Chicago Press (2001).

Van Voss, M.H., "Fähre", in: LÄ. II (1977),col. 85. , "Fährmann", in: LÄ. II (1977), col. 86.

Wilkinson, R.H., The Complete Gods and Goddesses of Ancient Egypt, AUC press, Cairo, 2003.

Willems, H., The Coffin of HeQata (Cairo JdE 36418 ), A case study of Egyptian funerary culture of the early middle kingdom, OLA. 70, Leuven (1996). 


\section{Figures}
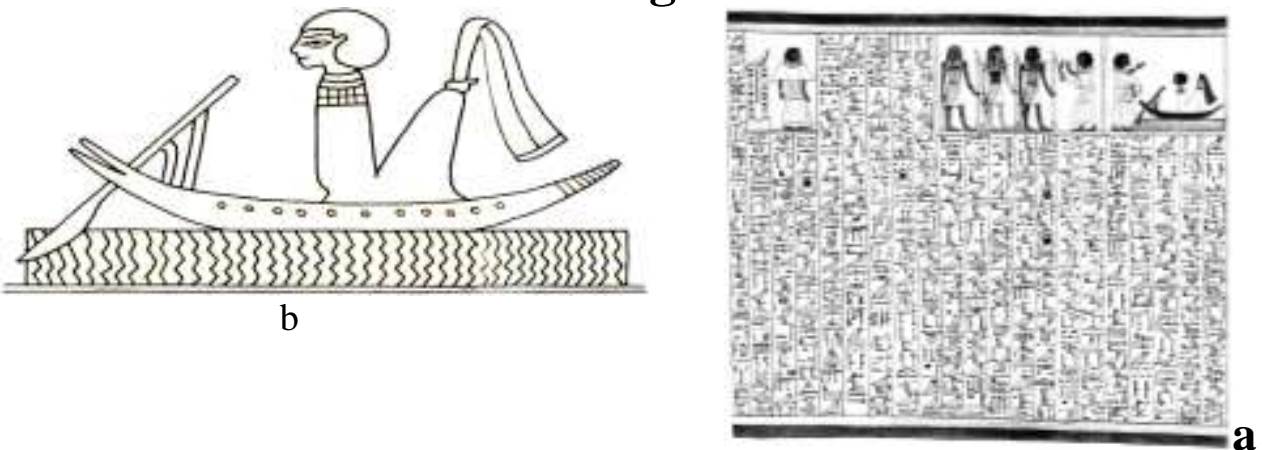

Fig. 1 a, b.

Hr.f-m-h3.f 'He whose face is behind him' is one of the many names of the god often called the 'Celestial Ferryman', New Kingdom Papyrus of Ani (A) and Anhai (B), British Museum. Faulkner, R.O., Book of the dead (pap. of Ani), plate 16 (right).

Wilkinson, R.H., Complete Gods and Goddesses, p. 104.

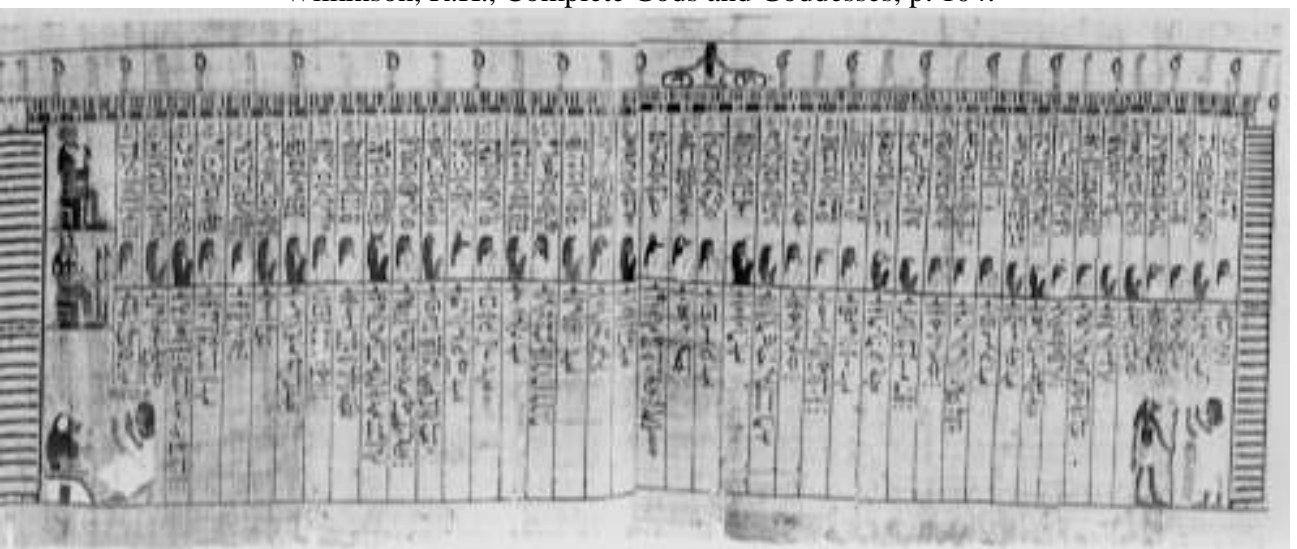

Fig. 2.

Spell 125 The Negative Confession. Within an elaborate shrine with open doors squat the Forty-Two Assessors of the dead, each is addressed by name and to each Nakht denies having committed a specific sin. The confession is witnessed by the enthroned falcon-headed sun-god and the two Maats, all carrying $W 3 s$-sceptres, and by Thoth as a baboon wearing the moon on his head and holding a scribe's palette. Among them the god number 27 is $H r . f-h$. $f$ as a judge.

Faulkner, R. O., Book of the Dead, pp. 27-29. 

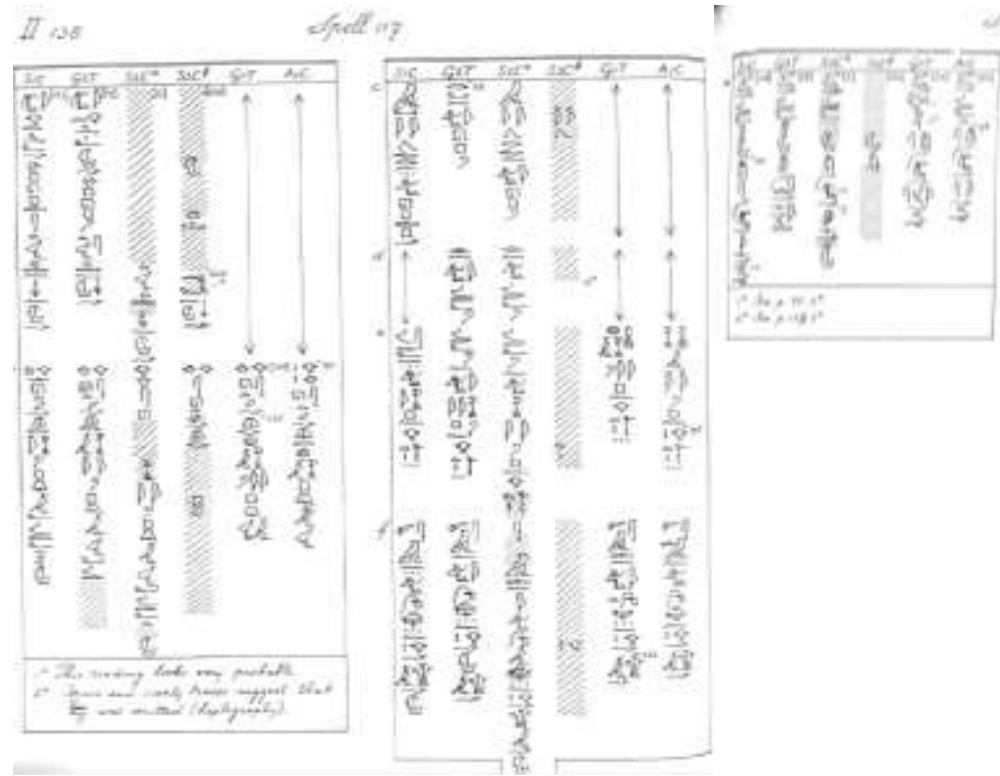

Wily

Ifise

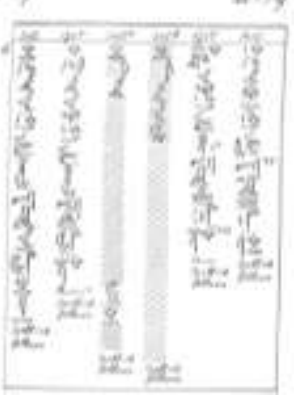

Fig. 3.

CT, spell 117 .

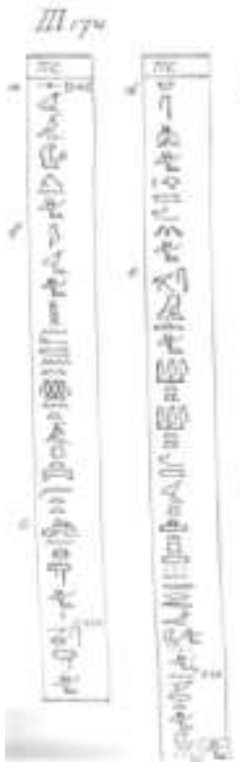

ofralles
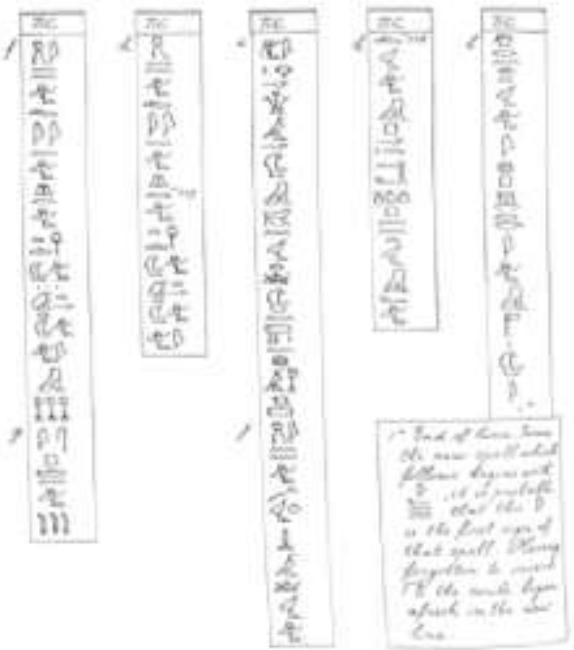

Fig. 4.

CT, spell 214. 
JOURNAL OF The General Union OF Arab Archaeologists (1)

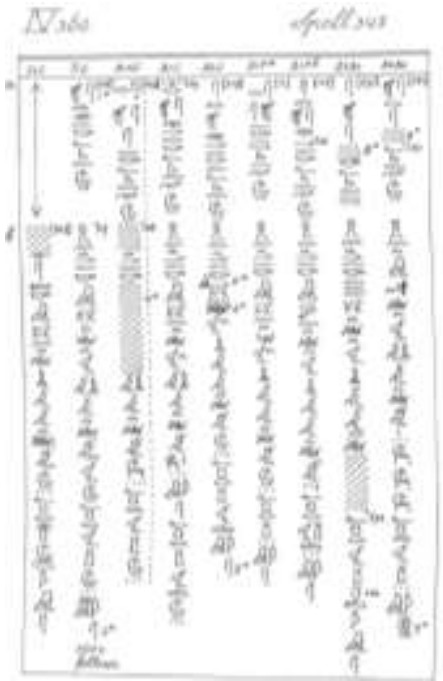

Fig. 6.

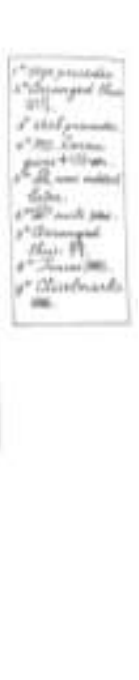

CT, spell 343a-b.

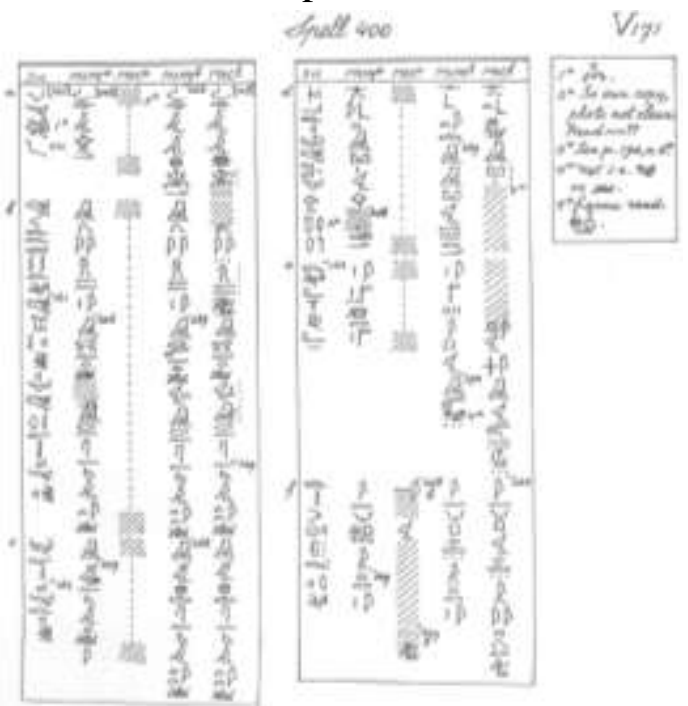

Fig. 8.

CT, spell 400a-f.
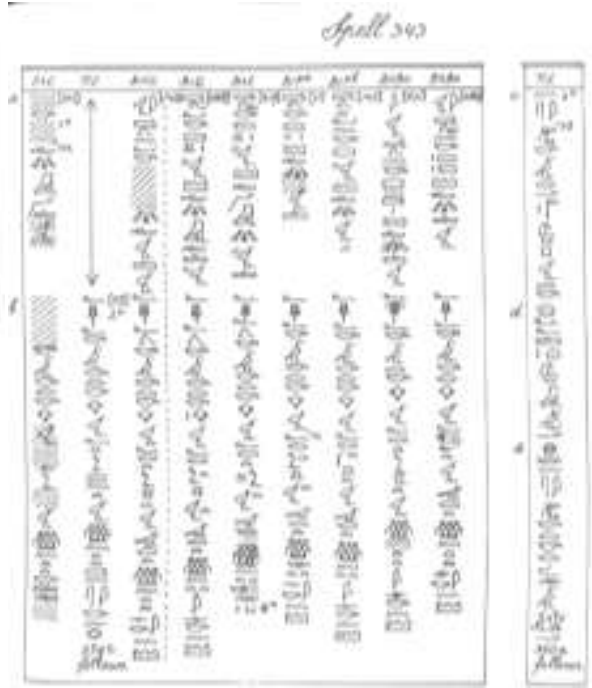

IVing

Fig. 5.

CT, spell 343c-e.

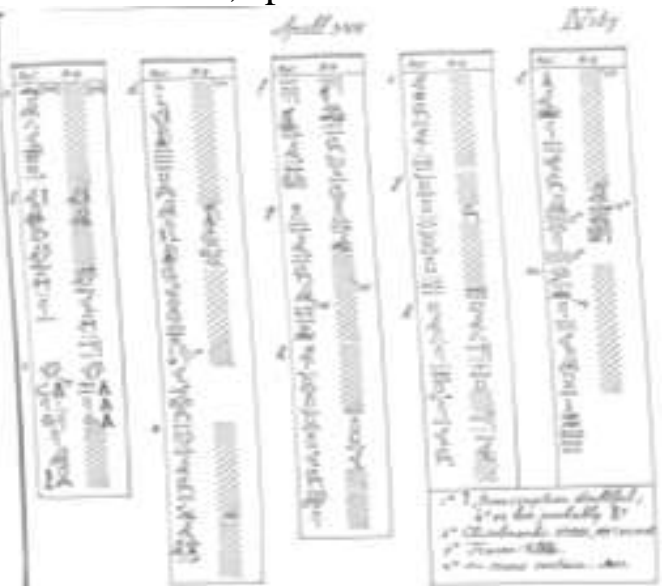

Fig. 7.

CT, spell 344e-h.

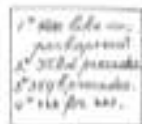




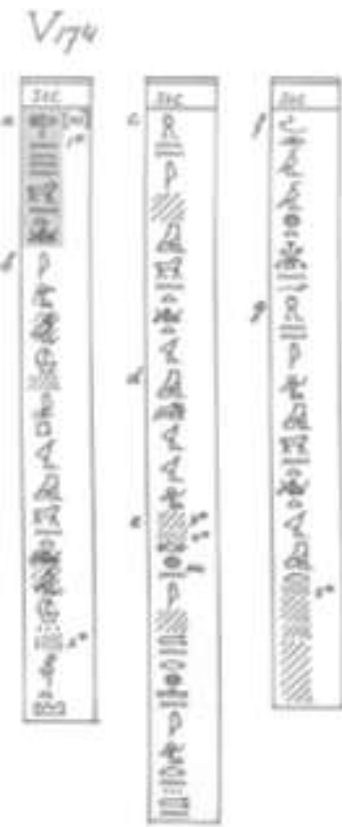

brallor
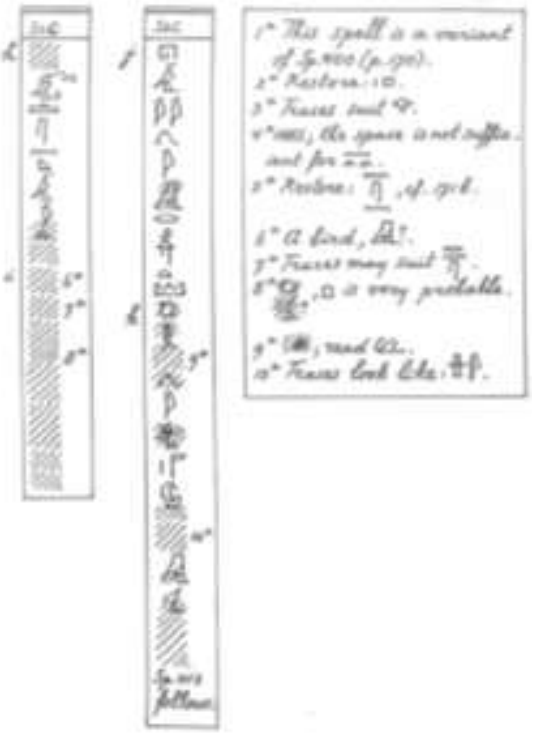

Fig. 9.

CT, spell 401a-k.

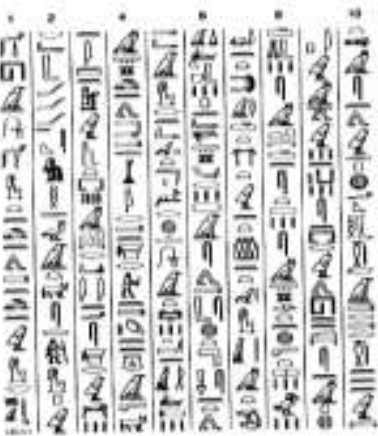

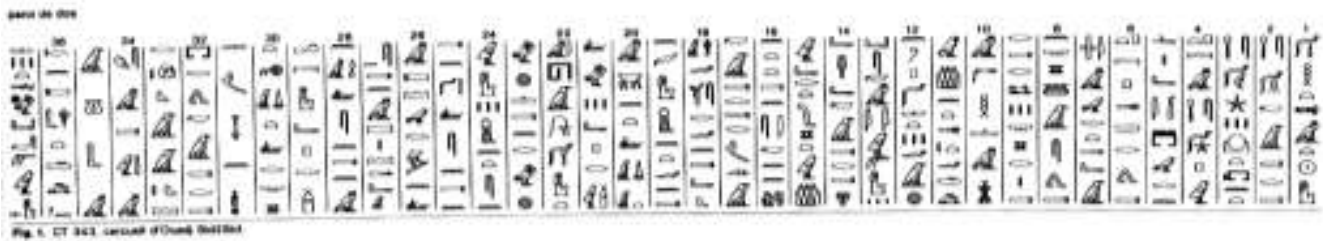

Fig. 10.

CT, spell 343(cols. 14-21).

The Coffin of lady Wadj from Sedment (Beni-Suif Meusum).

Abdel Fatah (Ahmed Galal) \& Bickel (Susanne), "Trois Cercueils de Sedment “, pp. 1, 3, 5, 8, fig. 1 et photos 3, 6. 


\section{المعداوي السماوي في الايانة المصرية القديمة (بحار الموتي)}

د. رضوان عبد الراضي سيد احمد سيده

الملخص:

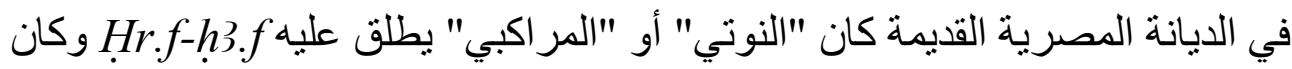
يصور كبحار يقف في مقدمة قارب البردي.

إن "المعداوي" المصري معروف في النصوص الجنائزية:

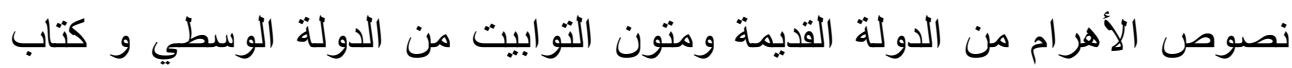

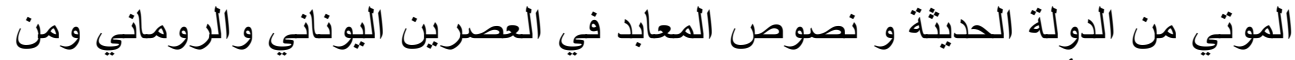

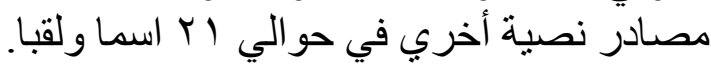

وفي كل تلك المصادر نجد أسمائه وألقابه وصفاته و أدواره ووظائفه وكذلك علاقاته مع المعبودات الأخري في مصر القديمة.

ولقد كان من الضروري للمتوفي أن يستدعي أو ينادي علي نوتيا في عبوره، ذلك لأندانه

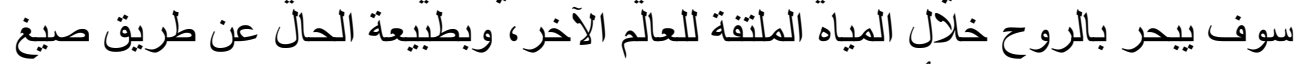
سحرية و التي تتضمن الأسماء الغامضة ولاه الخفية للمر اكبي.

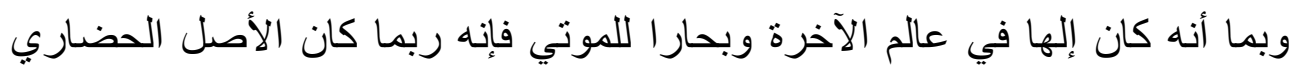

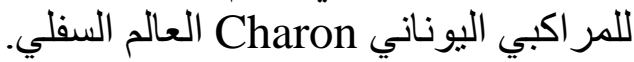

إن فكرة بحار العالم الأخروي لم توجد في مصر القديمة و اليونان فقط، ولكن وجدت الإن

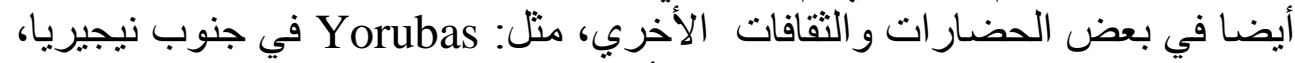

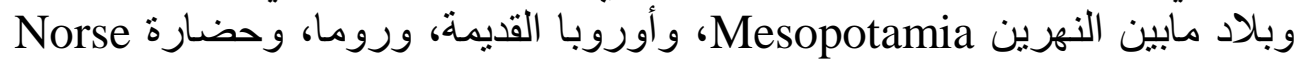
بالدنمارك (العصر البرونزي). تحاول هذه الورقة البحثية إعطاء فكرة تفصيلية عن هذه الثخصية الهامة و المقدسة

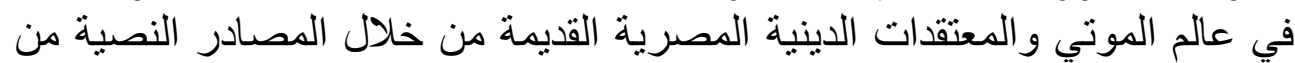

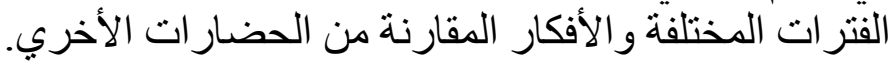
الكلمات الدالة :

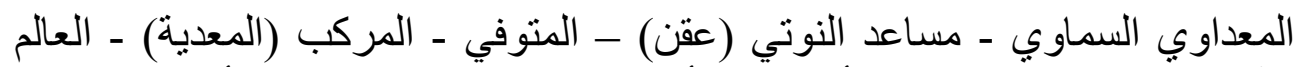

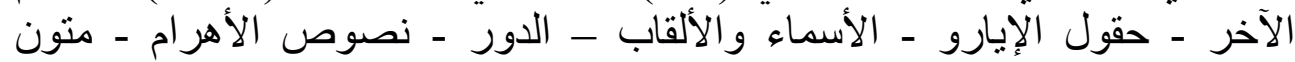
التو ابيت. - ت الاجر.

• مدرس بقسم الآثار المصرية كلية الآثار جامعة اسوان 